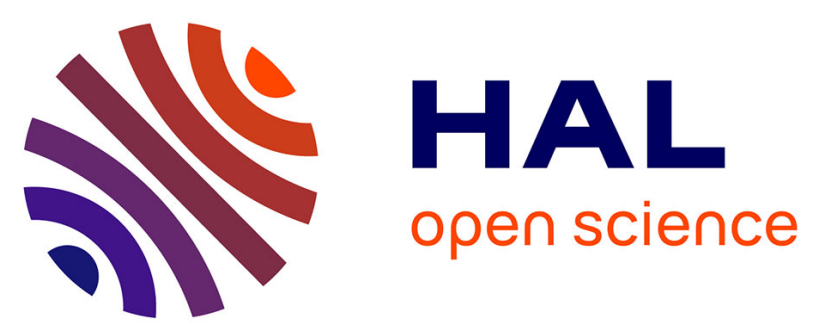

\title{
TRANSCRIPTIONAL REGULATION OF THE 11P15 MUCIN GENES. TOWARDS NEW BIOLOGICAL TOOLS IN HUMAN THERAPY, IN INFLAMMATORY DISEASES AND CANCER?
}

Isabelle van Seuningen, Pascal Pigny, Michael Perrais, Nicole Porchet, Jean-Pierre Aubert

\section{To cite this version:}

Isabelle van Seuningen, Pascal Pigny, Michael Perrais, Nicole Porchet, Jean-Pierre Aubert. TRANSCRIPTIONAL REGULATION OF THE 11P15 MUCIN GENES. TOWARDS NEW BIOLOGICAL TOOLS IN HUMAN THERAPY, IN INFLAMMATORY DISEASES AND CANCER?. Frontiers in Bioscience, 2001, 6. hal-02905799

\section{HAL Id: hal-02905799 https://hal.science/hal-02905799}

Submitted on 23 Jul 2020

HAL is a multi-disciplinary open access archive for the deposit and dissemination of scientific research documents, whether they are published or not. The documents may come from teaching and research institutions in France or abroad, or from public or private research centers.
L'archive ouverte pluridisciplinaire HAL, est destinée au dépôt et à la diffusion de documents scientifiques de niveau recherche, publiés ou non, émanant des établissements d'enseignement et de recherche français ou étrangers, des laboratoires publics ou privés. 
TRANSCRIPTIONAL REGULATION OF THE 11P15 MUCIN GENES. TOWARDS NEW BIOLOGICAL TOOLS IN HUMAN THERAPY, IN INFLAMMATORY DISEASES AND CANCER?

Isabelle Van Seuningen ${ }^{1}$, Pascal Pigny ${ }^{1,2,4}$, Michaël Perrais ${ }^{1}$, Nicole Porchet ${ }^{1,3,4}$, and Jean-Pierre Aubert ${ }^{1,3}$

${ }^{1}$ Unité INSERM 377, Place de Verdun, 59045 Lille cedex, France, and Laboratoires ${ }^{2}$ d'Endocrinologie et de ${ }^{3}$ Biochimie et de Biologie Moléculaire de l'Hôpital C. Huriez, CHRU, 59037 Lille cedex, France, ${ }^{4}$ Faculté de Médecine, Université de Lille II, 59045 Lille cedex, France.

\section{TABLE OF CONTENTS}

\section{Abstract}

2. Introduction

3. 11 p15 mucin gene expression is cell-and tissue-specific

4. Organization of the 11p15 mucin gene cluster

5. Structures of the promoters of MUC2, MUC5AC and MUC5B

5.1. Structure of the promoter of MUC2

5.2. Structure of the promoter of MUC5AC

5.3. Structure of the promoter of MUC5B

6. Transcriptional regulation of 11 p15 mucin genes by exogenous factors

6.1. Transcriptional regulation of MUC2

6.1.1. Regulation in colon cancer cells

6.1.2. Regulation in lung cancer cells

6.2. Transcriptional regulation of MUC5AC

6.2.1. Regulation by inflammatory mediators

6.2.2. Regulation via EGF-receptor $(E G F-R)$ signaling

6.3. Transcriptional regulation of $M U C 5 B$

6.3.1. Regulation of the promoter

6.3.2. Roles of intron 1 and intron 36 in MUC5B regulation

6.4. 11 p15 mucin gene regulation during mucous cell differentiation

6.5. 11 p15 mucin gene regulation by glucocorticoids and hormones

7. Transcriptional regulation of 11 p15 mucin genes by the Sp-family of transcription factors

8. Repression of 11 p15 mucin genes by methylation. Consequences during early development and tumorigenesis

9. Perspective

10. Acknowledgments

11. References

\section{ABSTRACT}

Mucin production and secretion by specialized epithelial cells is a common mechanism used by mammals to protect the underlying mucosae against various injuries (pollutants, pathogens, $\mathrm{pH}$ ). The expression of mucin genes is cell- and tissue-specific but is submitted to variations during cell differentiation, inflammatory process, and is altered during carcinogenesis. The molecular mechanisms responsible for the control of mucin transcription and expression are beginning to be understood as mucin gene promoters and regulatory regions are characterized. The four gel-forming mucin genes, $M U C 2-M U C 5 A C-M U C 5 B-$ MUC6, are clustered on the p15 arm of chromosome 11. Common regulatory mechanisms (PKA, PKC, PKG and $\mathrm{Ca}^{2+}$ signaling, Sp1/Sp3) may account for the capability of mucous-secreting cells to express several mucin genes simultaneously. In response to an insult or during carcinogenesis, the normal pattern of expression is altered and results from specific answers of the cell by activating different intracellular signaling pathways. $11 \mathrm{p} 15$ mucin genes are regulated at the transcriptional level by proinflammatory cytokines (IL-1beta, IL-6, TNF-alpha), pleiotropic cytokines (IL-4, IL-13, IL-9), bacterial exoproduct (LPS), growth factors (EGF, TGF-alpha), lipid mediator (PAF), retinoids and hormones. To date, the only downstream cascade known to activate mucin gene transcription is the $\mathrm{Src} / \mathrm{Ras} / \mathrm{MAPK} / \mathrm{pp} 90^{\text {rsk }}$ cascade, which leads to the activation of the transcription factor NFkappaB. Mucin gene transcription is also regulated by ATF-1, CREB and RAR-alpha transcription factors. Finally, repression of mucin transcription in cancer cells is under the control of the epigenetic mechanism of methylation. As transcriptional regulation of mucin genes begins to be unraveled, it becomes clear that many signaling pathways are involved. Our understanding of mucin gene transcriptional regulation, which awaits more data (identification of the signaling cascades and active cis- 
elements within promoters and introns), will most certainly lead to the use of mucin genes as molecular markers in cancer and molecular tools in human gene therapy, and to the synthesis of new therapeutic agents in inflammatory diseases of the epithelium.

\section{INTRODUCTION}

This review will focus on the regulation of expression of the human mucin genes $M U C 2, M U C 5 A C$, $M U C 5 B$ and MUC6 (1-3). These four genes are part of a mucin cluster long of $400 \mathrm{~kb}$ and located on the p15 short arm of the chromosome 11 (Figure 1) (4). They encode large secreted gel-forming mucins that contain transforming growth factor-(TGF)-beta-like domains in their C-terminal end (5) and have evolved from a common ancestor gene (6). The other family of mucin genes (MUC1, MUC3, MUC4, MUC11, MUC12) encodes transmembrane mucins $(7,8)$. Three of them, $M U C 3$, MUC4 and MUC12 contain epidermal growth factor(EGF)-like domains in their C-terminal end $(8,9)$. The genomic organization of the $11 \mathrm{p} 15$ cluster depicted in our laboratory (4) in parallel with an extensive amount of studies about their expression in normal (10) and pathological (11-16) tissues led us to hypothesize that these four genes, which are tightly regulated, may represent a new class of molecular markers in cancer and play important roles in epithelium tumorigenesis.

Mucin genes often show an altered expression during carcinogenesis (over-expression, repression, aberrant or neo-expression) $(12,17,18)$ and abnormal expression has been correlated to poor prognosis of the tumor (invasiveness) (19). Moreover, their early expression during mammalian development (20-23) and their position in the $11 \mathrm{p} 15$ cluster correlated with their major territory of expression along the antero-posterior axis indicate that these genes may be important during human embryogenesis and the establishment of cell lineages derived from endoderm (Figure 2). However, most of these studies remained descriptive due to the techniques used (northernblotting, in situ hybridization) that only measure the steadystate levels of mRNAs, and to the absence of knowledge about the structure and molecular mechanisms underlying the transcriptional regulation of mucin gene promoters. This lack of information was frustrating as it is mandatory in order to (i) explain how $11 \mathrm{p} 15$ mucin genes are regulated, (ii) provide insights in the pathological processes characteristics of chronic diseases of the lung and gastrointestinal tract or in pathologies of the mucosal surfaces in general and therefrom allow scientists to eventually use mucin promoters as biological tools in human gene therapy or mucin genes as markers in diagnostic. An extensive amount of literature about the regulation of $M U C 1$ exists (24-28) and has already pointed out to important roles for this transmembrane mucin in tumorigenesis by promoting invasion and metastasis (29, 30). It is at this time tested in trials in cancer immunotherapy $(31,32)$. So far, no data has been published on human MUC3, MUC4, MUC6, MUC11 and MUC12 promoters.
Yet, studies about the regulation of mucin secretion over the past 20 years has led to the identification of various stimuli allowing mucous-secreting cells possessing the appropriate receptors to activate intracellular transduction pathways and mediate mucin expression. Mucin secretion is as far as we know either basal (unregulated) or submitted to a tight regulation involving multiple receptor-mediated stimulatory pathways creating a complex interplay between the diverse pathways that lead to a specific response of the cell (33-36). The secretagogues known to induce mucin secretion via protein kinase $\mathrm{A}$ (PKA), PKC, PKG or $\mathrm{Ca}^{2+}$ signaling pathways are listed in Table 1. Other studies dealing with mucin secretion in pathological states have shown that inflammatory mediators such as interleukin-(IL)-1beta (37), IL-6 $(38,39)$ and tumor necrosis factor-(TNF)-alpha (40) are responsible for goblet cell metaplasia and mucin hypersecretion in inflammatory diseases of the lung (41) and gastrointestinal tract (42).

When promoter structures of $M U C 2$ (43, 44), $M U C 5 A C$ (45) and MUC5B (46) were characterized, authors looked for signaling pathways and transcription factors known to be activated by these secretagogues, inflammatory mediators and growth factors to demonstrate whether or not mucin gene expression was regulated at the transcriptional level. The strategy was to transfect cells with mucin gene promoters fused to reporter genes, treat transfected cells with the mediators of interest and measure the effect on transcriptional activity. In parallel, DNAprotein interaction studies by gel-retardation (EMSA) allowed the identification of transcription factors and their cognate cis-elements within the promoter. The next step will be to use receptor analogs, specific antibodies against receptors or chemical inhibitors to identify the cascade(s) of events, from the interaction of the stimuli (ligand) with its cell receptor to the activation and translocation to the nucleus of the activated transcription factor, that will end up activating mucin gene transcription.

The structures of the promoters of three of the $11 \mathrm{p} 15$ mucin genes, that is $M U C 2, M U C 5 A C$ and $M U C 5 B$ will be presented before describing the different stimuli and signaling pathways known, up to now, to regulate these genes. No data has been published regarding MUC6 promoter, so far. The implications in human pathophysiology (inflammatory diseases and cancer) will be discussed.

\section{3. $11 P 15$ MUCIN GENE EXPRESSION IS CELL- AND TISSUE-SPECIFIC}

In situ hybridization and northern-blotting studies performed in our group and others on normal tissues from different epithelial sources have shown that mucin gene expression is cell- and tissue-specific $(5,10,17,18)$. In general, mucin-producing cells (goblet cells of the surface epithelium or mucous cells of the submucosal glands) express a panel of mucin genes and not one. Common mechanisms of regulation are most likely responsible for this simultaneous expression of several genes. $11 \mathrm{p} 15$ mucin 
Table 1. Mediators known to induce mucin expression/secretion.

\section{Activators of phospholipase C (PLC)}

After binding to a G-protein-associated receptor, PLC is activated and will lead to the formation of $\mathrm{IP}_{3}$ or DAG. Consequent increase in intracellular $\mathrm{Ca}^{2+}$ will then activate PKC.

- Cholinergic agonists (muscarinic receptors): methacholine, carbachol

- Luminal ATP, UTP (P2 purinergic receptors)

- ADP

- Alpha ${ }_{1}$-adrenergic agonists $\left(\mathrm{IP}_{3}\right)$ : Methoxamine, substance $\mathrm{P}$

- Neuropeptides: neurotensine, neuromedine $\mathrm{N}$

\section{Activators of adenylate cyclase (AC)}

Activation of AC induces intracellular increase in cAMP used to phosphorylate and activate PKA.

- Neuropeptides: VIP

- Cholera toxin

- Prostaglandines E1, E2 et F2beta

- Secretine

- Beta-adrenergic analogs: isoproterenol

- Other neuropeptides, cathecholamines

- Biliary acids

\section{Activators of guanylate cyclase (GC)}

They induce intracellular increase of cGMP followed by activation of PKG.

- NO (nitric oxide) and NOS (nitric oxide species)

- Lipid mediator: PAF

\section{Inflammatory mediators}

Mucin secretion is under the influence of inflammatory mediators and goblet cell hyperplasia is mediated by T cells.

- IL-1alpha, IL-1beta

- Th2 cytokines: IL-4, IL-6, IL-9, IL-13

- Th1-Th2 cytokine: TNF-alpha

- Th1 cytokine: IFN-gamma

- MMS-68 (macrophage-derived protein 68)

$-\mathrm{C} 3 \mathrm{a}$

- Histamine

- Elastase, cathepsin G, chymase

- Free radicals, ROS (radical oxygen species)

\section{Other mediators}

These molecules are known to induce mucin secretion.

- Mustard oil

- Vitamin A et retinoids

- Bacteria and bacterial products: Pseudomonas aeruginosa, Helicobacter pylori, Entamoeba histolytica, Bordetella pertussis, LPS, rhamnolipids

- Hormones: estrogen, $\mathrm{T}_{3}$

- Glucocorticoids: dexamethasone, budenoside

- Plasma-derived product: bradykinine

- Tobacco-derived product: acrolein (aldehyde)

- Pollutant: ROFA

genes also show organ-specificity. In that case, they are often expressed as couples, one gene being expressed in surface epithelial goblet cells and the other one in mucous cells of the glands. For example in the respiratory tract, $M U C 5 A C$ is the major mucin gene expressed in surface goblet cells whereas $M U C 5 B$ is prominent in the mucous cells of the submucosal glands (15). In the stomach, $M U C 5 A C$ is again present at the surface of the epithelium whereas MUC6 is found within the glands $(22,47,48)$.
On the other hand, in pathological states, the pattern of expression is altered, showing that the cell specifically responds to different signals and activates new intracellular signaling pathways that in the end may affect the cell phenotype. Altered expression has been described in lung (15), esophagus (16), gastric (49), colon (18) and pancreatic (50) carcinomas. Most interestingly, altered mucin gene expression varies during the different steps of carcinogenesis (metaplasia, preneoplasia, neoplasia). This 


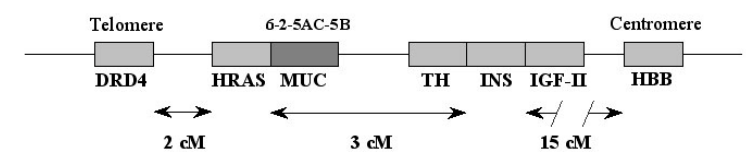

Figure 1. Position of the $M U C$ cluster within the $11 \mathrm{p} 15.5$ region.

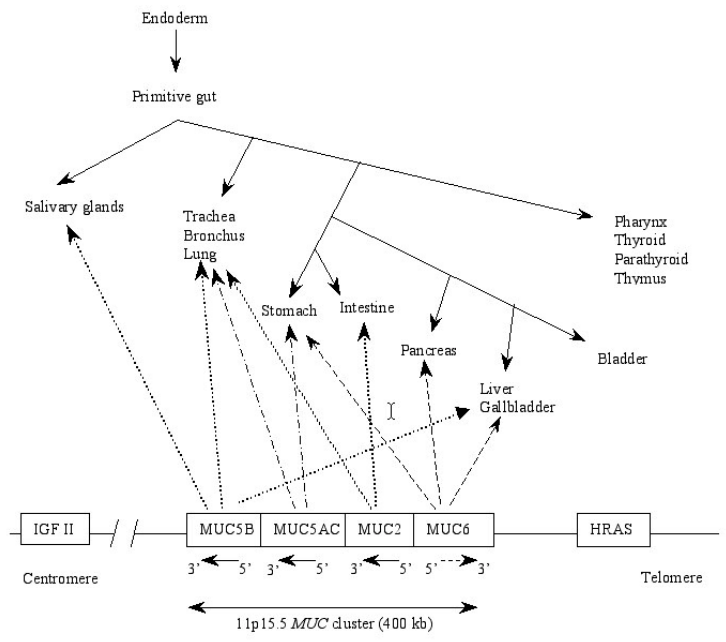

Figure 2. Correlation between the position of the $11 \mathrm{p} 15$ mucin genes within the cluster and their major expression territory along the antero-posterior axis.

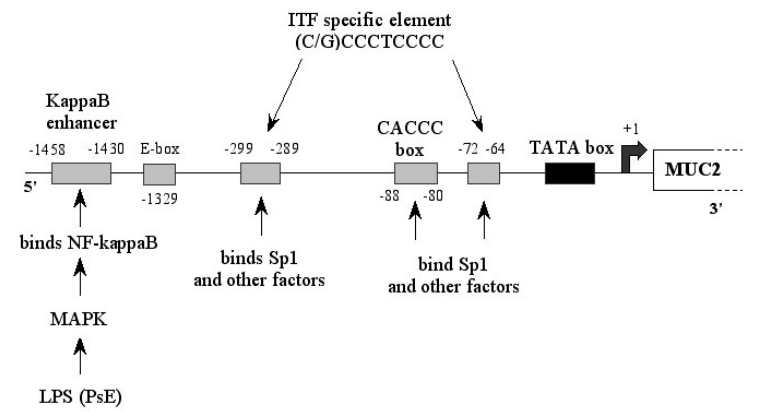

Figure 3. Schematic representation of the promoter of MUC2 and identified cis-elements.

has led to the hypothesis that mucin genes could be used as markers of tumor progression. For example, MUC5AC expression in rectosigmoid villous adenomas (RVAs) is postulated to be one of the early steps in a multi-stage process of tumorigenesis (12). Repression of transcription is either due to the activation of inhibitory cis-elements in promoters, to epigenetic modifications of DNA (methylation) and/or histone acetylation. Methylation of $M U C 2$ and $M U C 5 B$ promoters was shown to occur in colon (51) and gastric cancer cells (52), respectively. That mechanism was postulated to be responsible for the loss of $M U C 2$ and $M U C 5 B$ expression in the corresponding nonmucinous carcinomatous tissues.

Why does a cell need to express different kind of mucins, is it only a phenomenon of redundancy or do they play different roles due to (i) their final destination (secreted or anchored in the membrane), (ii) their level of glycosylation and the antigenic motifs that will then be exposed to the immune system, bacteria, endothelial cells, or substratum (iii) the presence of EGF-like (MUC3, $M U C 4, M U C 12)$ or TGF-beta-like (11p15 MUCs) domains in the C-terminal end of the proteins, that might display growth factor activity in an autocrine process where the epithelial cell would autoregulate the synthesis of its own pool of mucins? All these issues remain to be answered.

\section{ORGANIZATION OF THE $11 P 15$ MUCIN GENE CLUSTER}

This cluster contains the four mucin genes $M U C 2, M U C 5 A C, M U C 5 B$ and MUC6. The MUC cluster is located on the p15 arm of the chromosome 11 (4). It is long of $400 \mathrm{~kb}, M U C 6$ is the most telomeric gene whereas $M U C 5 B$ is at the centromeric end (Figure 1). The MUC cluster is located between the $H R A S$ and $I G F-I I$ loci. $M U C 2, M U C 5 A C$ and $M U C 5 B$ are transcribed in the same orientation (44) whereas MUC6's is opposite (53) (Figure 2). The $11 \mathrm{p} 15$ region is rich in $\mathrm{CpG}$ islands, in genes encoding tumor suppressor genes (WT1), growth factors $(I G F-I I)$ or oncogenes (HRAS) $(54,55)$ and genes submitted to imprinting (56). Most of the genes in that region are regulated by methylation in cancers (57-59) and not surprisingly, recent data regarding $M U C$ genes have demonstrated that methylation is used by certain colon and gastric cancer cells to repress expression of $M U C 2$ (51) and MUC5B (52) mucin genes, respectively.

\section{STRUCTURES OF THE PROMOTERS OF MUC2, $M U C 5 A C$ AND $M U C 5 B$}

\subsection{Structure of the promoter of $M U C 2$}

MUC2 is the major mucin expressed in normal colon (60) and as such the structure and activity of its promoter, the first promoter of the $11 \mathrm{p} 15$ mucin genes to be characterized, were studied in colon cancer cells $(43,44)$. The promoter is characterized by the presence of a typical TATA box located 25 nucleotides upstream of the transcriptional start site and by a CACCC box that lies between bases -88/-80 (GenBank accession number: U67167) (Figure 3) (43). A short fragment at $-91 /-73$ was shown to be essential for the basal activity of the promoter. The promoter region of $M U C 2$ seems to be separated in an AT-rich region from bases -4000 to -8000 , whereas downstream to -4000 the DNA sequence becomes GC-rich, to reach a maximum of $70 \%$. The authors have noticed the presence of several repeated motifs like the tetranucleotide motif ATCC repeated 101 times or the pentanucleotide CCTGC that is repeated 26 times but so far no precise role was identified for these repeats (43). Recently, this group showed that cell-specific elements driving MUC2 expression in granular goblet cells of the colon are present within the bases $-2864 /+17$ of the 5'-flanking region (61). The presence of a CT-rich element, also found in ITF (intestinal trefoil peptide) promoter, that is activated by the transcription factor GCBP, a transcription factor specific of goblet cells, raises the question whether mucins and trefoil peptides could be not only co-expressed by the same cells but also co-regulated and consequently be essential markers of goblet cell differentiation. A second group working on 
MUC2 promoter has sequenced $12 \mathrm{~kb}$ of the 5'-flanking region (GenBank accession number: U68061) and showed that the first 848 bp upstream of the transcription start site account for the maximal activity of the promoter in colon cancer cells (44). The upstream region that flanks the TATA box contains numerous putative binding sites for activator protein-(AP)-1, AP-2, cAMP-responsive element binding protein (CREB), thyroid hormone (TR), C/EBP, Adh1 (CCCGG), HC3 (CCACCA) transcription factors and one E-box (at -1329, putative binding site for c-Myc) (44) (Figure 3).

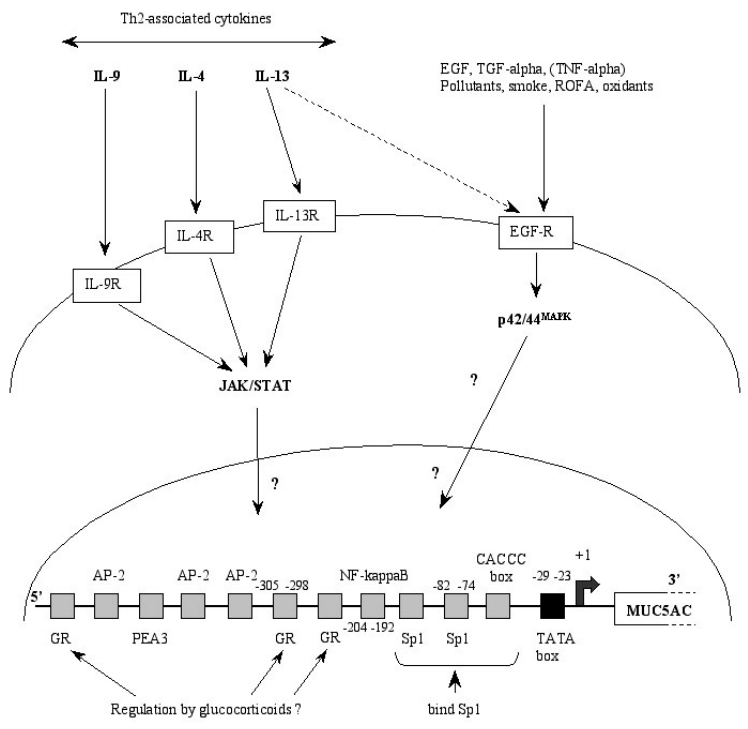

Figure 4. Schematic representation of the promoter of $M U C 5 A C$. Putative binding sites for transcription factors are shown as well as stimuli and signaling pathways that up-regulate $M U C 5 A C$ transcription.

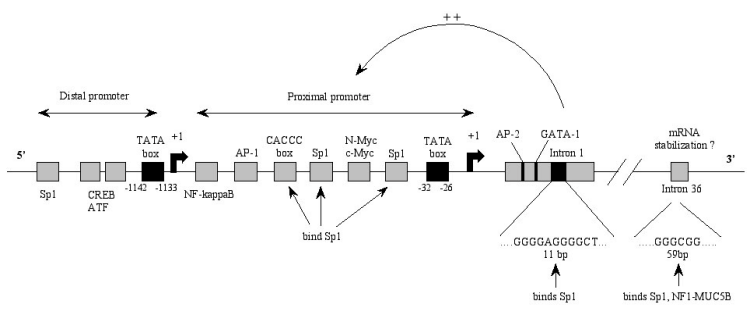

Figure 5. Schematic representation of the promoters of $M U C 5 B$ and introns 1 and 36. Identified cis-elements are shown.

\subsection{Structure of the promoter of $M U C 5 A C$}

The promoter of $M U C 5 A C$ also contains a TATA box located at -29/-23 upstream of the transcription initiation start site (45) (Figure 4). $1.6 \mathrm{~kb}$ of the 5 '-flanking region has been published so far (GenBank accession number: AF016834). It is characterized by numerous binding sites for Sp1, AP-2, glucocorticoid receptor element (GRE), PEA3, and NF-kappaB transcription factors. One CACCC box, a motif that is known to be able to bind $\mathrm{Sp} 1$ and initiate transcription, was also found. $M U C 5 A C$ promoter shows the typical organization of a promoter conferring cell-specific expression to the gene and authors mentioned that key cis-elements operate within $4 \mathrm{~kb}$ upstream of the transcription start site (45).

\subsection{Structure of the promoter of $M U C 5 B$}

This is the latest of the $11 \mathrm{p} 15$ mucin gene promoter that has been characterized. $4.5 \mathrm{~kb}$ upstream of the first transcription initiation site have been described so far (GenBank accession numbers: AJ011582 and AJ012453) (Figure 5). Two transcription units drive $M U C 5 B$ expression. The proximal promoter is characterized by a TATA box (TACATAA) located at $-32 /-26(46,62)$ and is under the control of the ubiquitous transcription factor $\mathrm{Sp} 1$ as well as methylation (52). Transcription factor NF-kappaB and oncogenes c-Myc and $\mathrm{N}-\mathrm{Myc}$ also bind to the proximal promoter (46). Studies in our group led to the characterization of a distal promoter also flanked by a TATA box (TAAATAAAA) and located $1.0 \mathrm{~kb}$ upstream of the proximal promoter (52). A transcription initiation site was found downstream of the distal TATA box and displayed a strong activity in KATOIII gastric cancer cells. The up-regulation of that distal promoter is thought to be responsible for the high and aberrant expression of $M U C 5 B$ in gastric carcinomas. The distal promoter, rich in activating transcription factor (ATF)/CREB cis-elements, is most likely under the control of this family of transcription factors.

It has been suggested that mucin genes may play important roles during development, in the establishment of cell lineages derived from endoderm $(22,23)$. Our hypothesis is that they may act as targets of transcription factors regulating respiratory (Hox, TTF-1, HNF-3, RARs, RXRs, c-Myc, N-Myc) (63) and intestinal (Cdx-1, Cdx-2, HNF-1, HNF-3, HNF-4, GATA-4/5/6) $(64,65)$ cell differentiation during development. Putative binding sites for such factors have been found in the promoters of $M U C 2$ (HNF-3, GATA-1), MUC5AC (HNF-1, GATA-1) (Van Seuningen I., unpublished results) and MUC5B (HNF-1, HNF-3, TTF-1, Hox, GATA-1, TGT3) (46, 52). We already showed that c-Myc/N-Myc and GATA-1 bind to the promoter and the first intron of $M U C 5 B$, respectively (46). Functional studies in progress in our laboratory will provide new insights as to whether or not the putative ciselements are active during cell differentiation.

\section{TRANSCRIPTIONAL REGULATION OF 11P15 MUCIN GENES BY EXOGENOUS FACTORS}

Studies about mucin gene transcriptional regulation has benefited from earlier studies on mucin secretion that led to the identification of a large variety of secretagogues. It has also benefited from studies about mucin gene expression in normal and pathological tissues in which steady-state levels of mucin gene mRNAs were detected by northern-blotting, RT-PCR or in situ hybridization. In vitro (epithelial carcinoma cell lines and primary normal epithelial cells) and in vivo (pathogen-free mice and rats, transgenic and knock-out mice) models are now used to investigate mucin gene regulation by 
exogenous factors (secretagogues, inflammatory mediators, growth factors and other effectors known to affect mucin expression/secretion). Availability of human and rodents mucin gene promoters will now allow studies in the same models to identify the molecular mechanisms responsible for mucin gene transcriptional regulation.

\subsection{Transcriptional regulation of $M U C 2$}

Since MUC2 is the major mucin expressed in colon (60) and was shown to be over-expressed in colon cancer as well as other inflammatory diseases of the gastrointestinal tract (66), much studies have been conducted in gastric and colonic cancer cells. However, data is also available from respiratory cell lines in which $M U C 2$ regulation was studied in parallel with that of MUC5AC.

\subsubsection{Regulation in colon cancer cells}

The first studies have focused on G-proteinassociated second mediators signaling pathways. Cells were stimulated with either forskolin (activator of PKA), A23187 (calcium ionophore), or 12-Otetradecanoylphorbol-13-acetate/phorbol 12-myristate 13acetate (TPA/PMA) (PKC activators) (Figure 6).

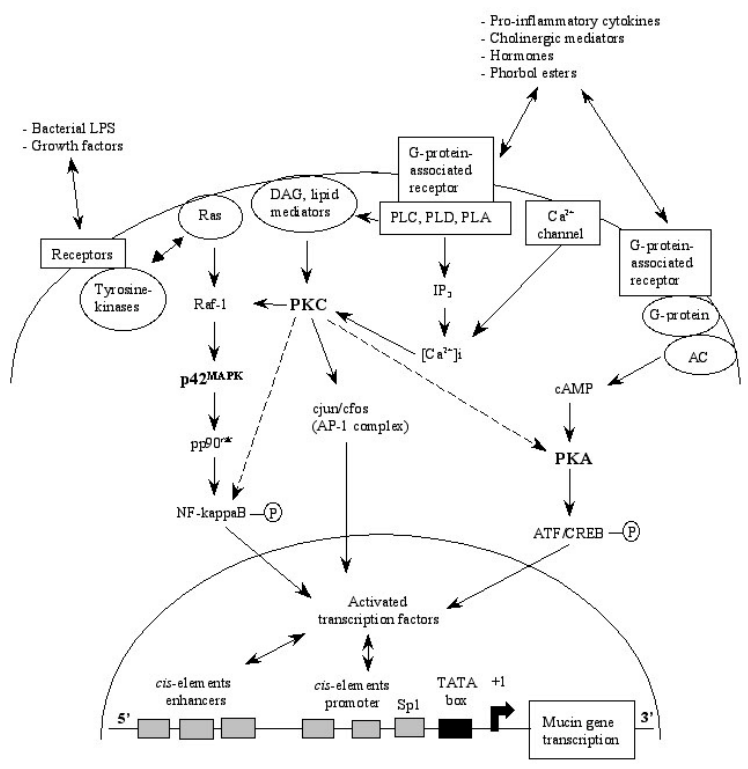

Figure 6. Cross-talk between PKA, PKC and MAPK intracellular signaling pathways. Relationships with $11 \mathrm{p} 15$ mucin gene transcription.

Effects on transcription was either measured by northernblotting, RT-PCR or after transfecting cells with promoter constructs. In HT-29 colon cancer cells, MUC2 gene expression is activated by PKC- and PKA-dependent signal transduction pathways (44). However, run-off experiments suggested that MUC2 accumulation in these cells was rather due to post-transcriptional mechanisms (67). It was suggested that TPA-induced-MUC2 mRNA accumulation was mediated via the transient induction of the AP-1 complex whereas forskolin induced post-translational modification of a pre-existing factor, most likely of the
CREB/ATF family. In another study, the authors showed that TPA- and cAMP-responsiveness of $M U C 2$ promoter was found in HeLa cells but not in colon cancer cells suggesting that $\mathrm{AP}-1$ and $\mathrm{AP}-2$ sites are inactive in these cells (44). In HM3 (68), T84 and HT-29/A1 (69) mucussecreting colon cancer cells, MUC2 and MUC5AC transcription was up-regulated by $\mathrm{PKC}$ whereas it had no effect on MUC5B and MUC6. In HT-29/A1 cells, MUC5B mRNA was even decreased after PMA treatment (69). Among the different isoforms of $\mathrm{PKC}, \mathrm{Ca}^{2+}$-independent PKC-epsilon was shown to be responsible for the upregulation of $M U C 2$ and $M U C 5 A C$ in colon cancer cells (69). Gum et al. (43) pointed out to a CACCC box that binds Sp1 and confers maximal activity in $\mathrm{C} 1$ a mucussecreting colon cancer cells and that bases between $-228 /-171$ conferred cell-specific activity to the promoter (Figure 3).

MUC2 is the prominent mucin in normal intestine and in colitis (60). In relation with ulcerative colitis (UC), Enss et al. (70) have looked at cytokine (IL-1, TNF-alpha and IL-6) effects on mucin mRNA levels in colonic LS180 mucus-secreting cancer cells. $40 \%$ of those cells contain intracellular mucin granules and MUC2 was shown to be up-regulated by the three cytokines. PKC appears as a good candidate as the signal transducer under these conditions as it is activated by these three pro-inflammatory cytokines. However, studies on $M U C 2$ transcriptional regulation in gastric cells (in relation with $M U C 2$ over-expression during intestinal metaplasia before gastric adenocarcinoma) and in colonic cells (in relation with the over-expression of $M U C 2$ in colon adenocarcinoma and in inflammatory bowel diseases such as Crohn's disease (CD), UC, and RVA) remain sparse and ask for more detailed analyses in order to identify the cis-elements in the promoter and/or in introns that are recognized by transcription factors activated by IL1, TNF-alpha and IL-6. Two recent studies, however, suggested that increased MUC2 detectability in UC and CD was due to post-transcriptional processing and that it was related to the inflammatory process $(71,72)$.

Many studies have led to the postulate that common regulatory pathways exist besides specific regulation of each mucin gene of the $11 \mathrm{p} 15$ cluster. The study by Enss et al. in LS180 cells (70) pointed out again to the complex regulatory mechanisms that may be responsible for the specific mucin gene profile of expression that is characteristic of a particular pathophysiological state of the cell. Cross-talk between different signaling pathways most likely occurs and contributes to the complexity of our understanding of mucin gene regulation. For example, in the normal colon $M U C 2$ is the prominent mucin gene (60) whereas MUC5AC is not expressed (10). However they are frequently co-expressed in goblet cells in the presence of duodenal and colonic inflammation (73). These two genes are also over-expressed in gastric metaplasia (MUC5AC) and intestinal metaplasia (MUC2), two inflammatory responses that precede later stages of carcinogenesis in colon and gastric cancers, respectively. Thus, there is pathological evidence for $11 \mathrm{p} 15$ mucin gene co-regulation by inflammatory mediators in intestinal cells. From Enss's 
study, one can hypothesize that the same signaling pathway is used by IL-1 to up-regulate $M U C 2$ and $M U C 5 A C$, by IL6 to induce $M U C 2, M U C 5 B$ and $M U C 6$ and by TNF-alpha for $M U C 2$ and $M U C 5 B$ (70). How does the cell discriminate between the numerous signaling pathways that lead to mucin gene activation? How does the selection occur within the $M U C$ cluster to activate/repress one gene or another? All these important issues remain to be addressed and await the characterization of the promoter of the fourth gene of the cluster, that is MUC6.

\subsubsection{Regulation in lung cancer cells}

MUC2 transcriptional regulation in lung cells has benefited from studies conducted by the group of Carol Basbaum, who has focused for these past few years on studying the influence of various mediators on mucin gene expression in cystic fibrosis (CF). They have demonstrated that lipopolysaccharide (LPS) secreted by Gram-negative Pseudomonas aeruginosa (PsE), a virulent bacterium that colonizes the lungs of $\mathrm{CF}$ patients and is associated with airway plugging due to over-production of mucins, activates the $\mathrm{Src} / \mathrm{Ras} / \mathrm{MAPK} / \mathrm{pp} 90^{\text {rsk }}$ signaling pathway. Activated NF-kappaB, then translocates to the nucleus and activates the transcription of MUC2 (Figure 7). These studies were the first ones to use specific chemical inhibitors (capable of inhibiting each step of the signaling cascade from the membrane-associated tyrosine kinases to the serine-threonine cytoplasmic kinases) and dominant negative mutants (74-76). Two PsE-sensitive cis-elements were identified by EMSA. A distal kappaB element $(-1458 /-1430)$ binds the transcription factor NF-kappaB (Figure 3) whereas the proximal enhancer $(-343 /-73)$ binds a nuclear factor yet to be identified $(75,76)$. The same group widened their studies to other pathogens and showed that Gram-negative (Escherichia coli) and Gram-positive (Staphylococcus aureus, S. epidermidis, S. pyogenes) bacteria also activate $M U C 2$ expression (77). However, the Gram-positive $M U C 2$ response element is located further upstream in the promoter and does not contain a kappaB site (76).

Among pro-inflammatory mediators, TNF-alpha (40) and IL-1beta (78) have been shown to up-regulate MUC2 transcription in the lung mucoepidermoid NCIH292 adenocarcinoma cell line. TNF-alpha also upregulates MUC2 expression in gastric cancer cells (79). Most interestingly, Kim et al. showed that budenoside (a glucocorticoid) inhibited the IL-1beta-mediated $M U C 2$ upregulation (78). Glucocorticoids are at this time, efficiently used to decrease mucus hypersecretion in nasal and lung inflammatory airways. It is postulated that they do so by inhibiting IL-1beta-mediated mucin gene up-regulation. To these studies, in which mRNA content was measured by RT-PCR and transcriptional regulation was either confirmed by run-on assays, or by the use of the protein synthesis inhibitor cycloheximide and transcription inhibitor actinomycin D, it will be necessary in the future to identify and localize active cis-elements in the promoter and/or introns of $M U C 2$ and the intracellular signaling events activated by IL-1beta and TNF-alpha.

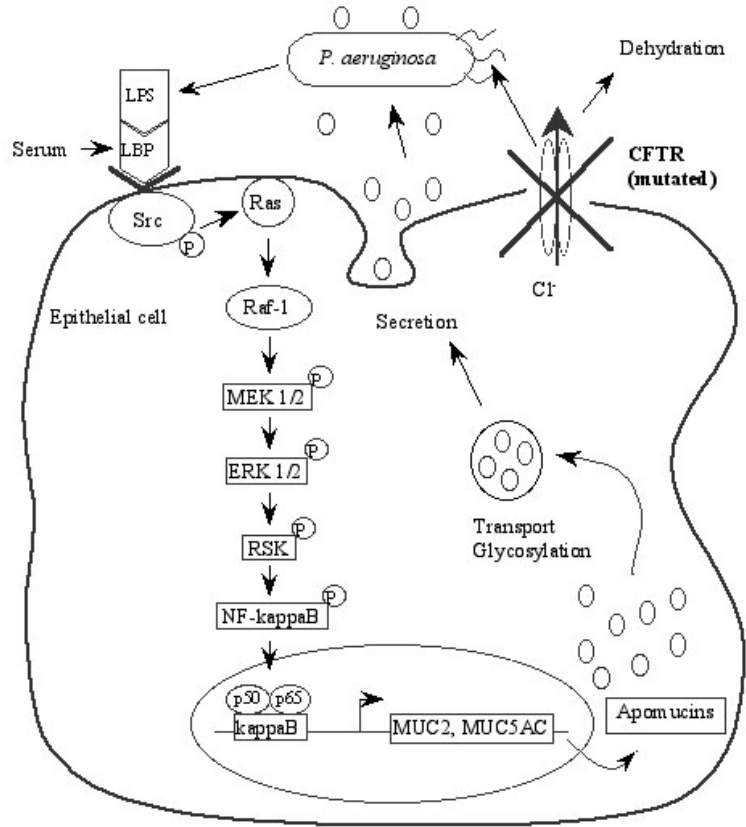

Figure 7. LPS-mediated up-regulation of $M U C 2$ and MUC5AC in lung epithelial cells goes through Ras/MAPK/pp90rsk pathway (from ref. 75).

\subsection{Transcriptional regulation of $M U C 5 A C$}

$M U C 5 A C$ being one of the major mucin gene expressed in the lung (goblets cells of the surface epithelium), much of the work has focused on its regulation by T-helper-(Th)-1- and Th2-associated inflammatory mediators (TNF-alpha, IL-1beta, IL-4, IL-9, IL-13), bacterial exoproduct (LPS), oxidants (nitric oxide, NO), pollutants, cigarette smoke, retinoids and growth factors involved in inflammatory diseases of the lung as well as lung cancer (Figures 4 and 8). It will be however important to look at signaling pathways activated by other environmental factors that are known to ensure an efficient response in immune and inflammatory lung diseases. Nuclear factors to be looked at are NF-kappaB, AP-1, NFIL6, NF-AT, GR, CREB, GATA and STAT (80).

\subsubsection{Regulation by inflammatory mediators}

Studies in IL-4 transgenic mice showed that IL-4 induces MUC5AC transcription in non-ciliated cells followed by MUC5AC mucin protein synthesis (81). At this time, the authors do not know whether this occurs via (i) direct up-regulation of MUC5AC transcription by IL-4 via the STAT signaling pathway, (ii) via an IL-4-activated second mediator that then activates MUC5AC transcription, (iii) or whether MUC5AC up-regulation is a consequence of the IL-4-mediated metaplastic transformation of nonciliated cells into goblet cells. These authors also showed that IL-4 does not up-regulate $M U C 2$ transcription and that other transgenic mice models (IL-6, IL-11 and IL-5) did not induce mucin over-production (81). Another study conducted in vitro (NCI-H292 cells) and in vivo (pathogenfree mice) showed that IL-4 directly induces goblet cell metaplasia. However, direct effect on MUC2 and MUC5AC 
transcription could not be proved and remains to be studied in this model (82). Authors had no explanation as to why, in vitro, MUC2 mRNA content was higher after IL-4 treatment when MUC5AC mRNA level was unchanged, whereas opposite effects were observed in vivo (increase of $M U C 5 A C$ mRNA and no effect on $M U C 2$ ).

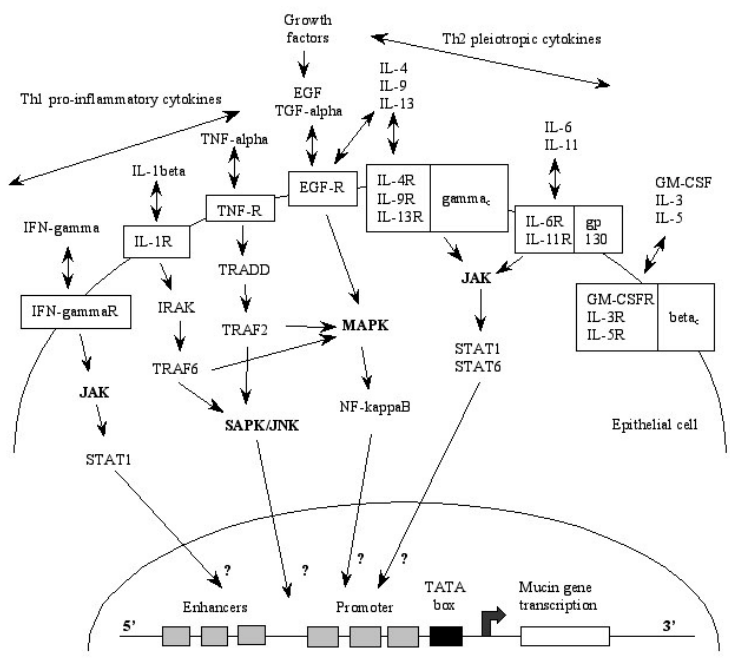

Figure 8. Mediators (growth factors and cytokines) and downstream intracellular signaling pathways involved in the regulation of $11 \mathrm{p} 15$ mucin gene transcription.

Lipid metabolites have also been implicated in leukocyte trafficking, in airway hyperactivity and mucus secretion. Among them, 15-lipoxygenase (15-LO) metabolites were shown to stimulate mucin secretion (83, 84) when 15-LO expression is activated by IL-4 in A549 lung carcinoma cells (85). The group of Nettesheim tried to link IL-4-mediated mucus secretion to IL-4-mediated 15LO expression (86). For that they chose the wellcharacterized model of normal human tracheobronchial epithelial cells (NHTBE) described by Gray et al. (87) that allow studies about differentiation of these cells into a mucociliary epithelium. Surprisingly enough, IL-4 treatment of NHTBE cells did not lead to an increase in mucin secretion but to a decrease. Moreover, MUC5AC and $M U C 5 B$ transcription was also inhibited. To explain the discrepancy with previous studies that had showed a positive effect of IL-4 on mucin secretion and expression $(81,83,84)$, they speculated that it was due to the experimental model used. It would be either an indirect effect of IL-4 on immune cells and IgE production (81), due to the presence of mesenchymal and inflammatory cells in bronchial explants (83) or to the difference between human and guinea pig tracheobronchial cells in responding to 15-LO (84). Studies about IL-4 effects on mucin gene promoter activity may provide an explanation to these discrepant results and show whether or not IL-4 has a direct effect on mucin gene transcription. Because IL-4R and IL13R heterodimerize with the same kind of receptors (gamma $_{c}$ chain) (Figure 8) and consequently induce the same intracellular signaling pathways (88), it will be of interest to look at IL-13 effects on mucin gene regulation as well. A recent study performed in pathogen-free mice, which contain only few, if any, mucus-producing cells, showed that IL-13-challenged animals presented a goblet cell metaplasia and an increase in MUC5AC expression both at the mRNA and protein level; no effect was seen on $M U C 2$ expression (89).

A few other studies have been conducted about lipid mediators effect on $11 \mathrm{p} 15$ mucin gene regulation. In inflammatory airway diseases, prevalent lipid mediators include prostaglandins, leukotriens, hydroxyeicosatetraenoic acids (HETEs) and platelet-activating factor (PAF). These lipid mediators are produced both by infiltrating inflammatory cells and epithelial cells in response to a number of stimuli. They, in turn, act as primary or secondary mediators of airway inflammation (39). In the lung, primary inflammatory mediators include interferongamma (IFN-gamma) and TNF-alpha, which in turn can provoke production of secondary mediators by epithelial cells, including lipid mediators, cytokines (IL-6, IL-8, GMCSF, IGF-I), reactive oxygen (superoxide anion radical, hydroxyl radical, hydrogen peroxide) and nitrogen (NO, and peroxynitrite) species. These secondary mediators because they further affect pathophysiological alterations such as hypersecretion of mucus and increased inflammation are regarded as potent actors in the pathogenesis of respiratory diseases such as asthma and chronic bronchitis. IL- 6 for instance has direct effect on epithelial cells by increasing secretion of mucus (most likely preformed mucus stocked in granules of goblet cells) and steady-state level of $M U C 2$ mRNA (38). The latter study performed in guinea pigs and rats confirmed the fact that PAF induces goblet cell hyperplasia and MUC5AC expression (90). PAF effect on cell hyperplasia was potentiated by pro-inflammatory cytokine TNF-alpha, however TNF-alpha itself had no effect on MUC5AC expression.

In summary, there is strong evidence for PAFinduced goblet cell hyperplasia and mucin secretion during inflammatory diseases of the airways. PAF-mediated upregulation of $M U C 5 A C$ could be under the control of $\mathrm{PKC}$ signaling pathway via activation of phospholipase C (PLC) and production of diacylglycerol (DAG) and inositoltriphosphate $\left(\mathrm{IP}_{3}\right)$ (Figure 6). However, PAF could also induce mucin secretion via activation of $\mathrm{PLA}_{2}$, formation of arachidonic acid and consequently production of eicosanoids, by lipoxygenase and cycloxygenase, that are potent mucin secretagogues. The PKC isoform involved in PAF-mediated mucin secretion remains to be identified. PKC-zeta isoform was found to be translocated to the membrane after PAF treatment but no correlation was made with induction of mucin expression/secretion (91). PAF effects during the inflammatory reaction could be potentiated by inflammatory mediators such as TNF-alpha, IL-1beta and LPS because they are known to inhibit PAF acetylhydrolase that is the enzyme responsible for the breakdown of PAF (92).

IL-4, IL-13 and PAF thus can be considered as potent mediators of inflammation in the airways and 
contribute to airway plugging and increase morbidity and mortality associated with asthma, bronchitis and CF. $M U C 5 A C$ seems to be the major mucin gene targeted during goblet cell hyperplasia and metaplasia in the lung. Studies of its regulation at the molecular level will certainly be encouraged and needed to elucidate the mechanisms underlying human airway remodeling and prove relevant to the successful treatment of asthma and inflammatory diseases of the lung.

Interleukin-9 (IL-9), another Th2-associated cytokine, is also able to activate mucin gene expression and mucin production (Figure 8). In the first study, IL-9 was shown to stimulate MUC5AC transcription but only accounted for $50-60 \%$ of the mucin-stimulating activity of lung fluids in allergic airway disease, thus leaving room for other inflammatory mediators (93). Based on their results and those from other authors, IL-8, IL-5 and IL-13, which failed to activate $M U C 5 A C$ transcription in in vitro assays, were eliminated. Longphre et al. proposed it could be IL-4 In another study, MUC2 and MUC5AC up-regulation by IL-9 was shown in vivo in transgenic mice whereas Th1associated cytokine IFN-gamma failed to induce them (94). They confirmed their in vivo studies by in vitro experiments in the mucoepidermoid NCI-H292 cell line.

Other inflammatory mediators that have been shown to increase MUC5AC transcription, include LPS (74) and human neutrophil elastase (HNE) (95). In that work, authors showed that active HNE increases MUC5AC mRNA level by enhancing mRNA stability both in A549 lung adenocarcinoma and NHTBE cells. That phenomenon was restricted to serine-proteases. Goblet cell metaplasia and increase in production/secretion of MUC5AC by HNE was then shown to be mediated by the induction of reactive oxygen species (ROS) (96). It remains to be demonstrated whether ROS are responsible for the increase of MUC5AC mRNA stability following increase of intracellular oxidant stress by HNE, by identifying the downstream events triggered by ROS.

Now that several pro-inflammatory cytokines have emerged (IL-1beta, IL-4, IL-9, IL-13, TNF-alpha) as pro-mucin agents, it is time to turn to intracellular signaling and decipher the cascade of events that leads to mucin gene transcription up-regulation. Several pathways will have to be investigated in relation with the cytokine of interest and its involvement in human pathology (Figure 8). IL-1beta triggers the mitogen-activated protein kinase (MAPK) cascade and activation of NF-kappaB. The SAPK/JNK signaling pathway will also have to be closely studied as IL-1 and TNF-alpha activate this cascade. IL-4, IL-13, IL9, and IL-6 bind to their specific receptor which in turns heterodimerizes with gamma $\mathrm{c}_{\mathrm{c}}$ chain or gp130 molecule to activate intracellular signaling. The Janus activated kinase/signal transducers and activator of transcription (JAK/STAT) pathway seems to be of great interest as IL-6, IL-13 and IL-4 (97) trigger STAT1 and STAT6 and IL-9 effect on hematopoietic cells activates that pathway as well (98).

\subsubsection{Regulation via EGF-receptor (EGF-R) signaling}

Besides inflammatory mediators, growth factors could be involved in goblet-cell production because hypersecretory diseases are associated with abnormal epithelial cell growth and differentiation and epithelium wounding leads to repair and remodeling processes (99). The group of Nadel postulated that EGF and its receptor EGF-R could be a good candidate. In airways, EGF-R is expressed in fetus, where it is involved in cell proliferation, branching, morphogenesis and epithelial cell differentiation (100). Its expression is sparse in the adult lung but is expressed in lung tumors, asthma and is up-regulated by the pro-inflammatory cytokine TNF-alpha. This group chose to study that pathway both in vitro with the NCI-H292 mucoepidermoid cell line which expresses MUC5AC and in vivo with pathogen-free rats because they have few, if any, goblet cells. They successively showed that activation of EGF-R tyrosine kinase by its ligands (EGF, TGF-alpha) leads to the synthesis of MUC5AC mRNA and protein in vitro and MUC5AC mucin production and goblet cell metaplasia in vivo. In vitro, this phenomenon was potentiated by TNF-alpha (101). Oxidative stress $\left(\mathrm{H}_{2} \mathrm{O}_{2}\right.$, supernatant of activated neutrophils) induced MUC5AC mRNA and protein up-regulation in NCI-H292 cells. Using specific inhibitors, the authors demonstrated that this occurred via a ligand-independent EGF-R activation that leads to the activation of the MAPK kinase (MEK)$\mathrm{p} 44 / 42^{\mathrm{MAPK}}$ signal transduction pathway (102) (Figure 4). These results led them to study the effect of cigarette smoke, agarose plug instillation on goblet cell hyperplasia and $M U C 5 A C$ up-regulation by EGF-R $(103,104)$. The same mechanism of MUC5AC induction exists in nasal polyps (105). In the three studies, they confirmed the use of EGF-R signaling pathway to induce mucin expression and mucus production. Their studies certainly provide new strategies for therapy in airway hypersecretory diseases in which one should try to efficiently and selectively inhibit EGF-R signaling pathway to reduce/prevent mucin hypersecretion.

Acrolein, an irritant present in tobacco smoke, also increases MUC5AC mRNA level in NCI-H292 cells (106). Inflammatory mediators $\left(\mathrm{PGE}_{2}, 15\right.$-HETE, TNFalpha) and phorbol ester (PMA) that are released after exposure to acrolein in acute and chronic airway inflammation increased MUC5AC mRNA levels in these cells. On the contrary, MUC5B mRNA levels were unchanged. That phenomenon was associated with chronic monocytic inflammation during which macrophage accumulation augments acrolein-induced MUC5AC synthesis and secretion (107). MUC2 on the other hand is not affected by acrolein exposure. Air pollution is known to induce airway mucus hypersecretion and increase susceptibility to infection. A particular interest in residual oil fly ash (ROFA), a PM10 particle pollutant, has led Longphre and co-authors to study its effect on mucin gene expression. Again $M U C 5 A C$ mRNA levels increased after ROFA exposure and was shown to go through a phosphotyrosine-dependent pathway (108).

IL-13 up-regulates MUC5AC expression after binding to its specific receptor (IL-13R) (89). However, IL- 
13-mediated mucin expression/secretion and goblet cell metaplasia in airways also occurs via activation of EGF-R signaling pathway. IL-13 would be responsible for leukocyte recruitment to the inflammatory site via activation of IL-8 chemoattractant expression (109). TNFalpha and oxygen free radicals released by neutrophils would activate EGF-R expression and EGF-R tyrosine kinase phosphorylation, respectively, resulting in mucin (MUC5AC) production. Thus IL-13 appears to be able to activate two signaling pathways (JAK/STAT or MAPK) depending on which receptor it interacts with (IL-13R or EGF-R) after being stimulated during inflammation (88, 109) (Figures 4 and 8).

\subsection{Transcriptional regulation of $M U C 5 B$}

\subsubsection{Regulation of the promoter}

The promoter of $M U C 5 B$ contains active cellspecific cis-elements that confer maximal activity of the gene in LS174T mucus-secreting colon cancer cells. The promoter is inactive in Caco-2 enterocytes and HT-29 STD undifferentiated colon cancer cells (46). The minimal fragments that confer maximal activity of the proximal and distal promoters cover bases -223/-1 and -1329/-1117, respectively (Figure 5). The proximal promoter is under the control of Sp1 and methylation. The distal promoter binds $\mathrm{Sp} 1$ and ATF/CREB factors and is transactivated by CREB (52). Those are known to be activated by the cAMP signaling pathway (110) as well as the $\mathrm{p} 38^{\mathrm{MAPK}}$. However, preliminary data suggest that AP-1 complex, composed Jun homodimers or Jun/Fos heterodimers, may also form heterodimers with ATF/CREB as PMA, a potent activator of PKC, was able to significantly induce $M U C 5 B$ activity in $M U C 5 B$-expressing gastric and colonic cancer cells $(46,52)$.

\subsubsection{Roles of intron 1 and intron 36 in $M U C 5 B$ regulation}

Having sequenced the genomic DNA encompassing MUC5B mucin gene, we looked into potential regulatory regions in the first introns as well as in the 3' region of the gene. The first intron is $2.5 \mathrm{~kb}$ long, which is rather large, and most interestingly possesses a GA-rich cluster of eight 11-bp-long DNA motifs (GGGGAGGGGCT) repeated in tandem (46). This cluster binds and is transactivated by $\mathrm{Sp} 1$ and thus represents another important regulatory region. The first intron appears to certainly have important roles in regulating $M U C 5 B$ expression as we also showed that GATA-1 and AP-2 transcription factors bind to their cognate ciselements (Figure 5).

We also studied the so-called intron 36 (the $37^{\text {th }}$ in order), located approximately $30 \mathrm{~kb}$ downstream of the first ATG, because it contains a striking feature made of 8 GC-rich DNA stretches long of $59 \mathrm{bp}$, each containing a GC box (GGGCGG), repeated in tandem (111). By the means of EMSA and southwestern-blotting we showed that Sp1 and a $42 \mathrm{kDa}$ nuclear factor named NF1-MUC5B, yet to be identified, bind to intron 36 (112). Later, 5 allelic forms $(3,4,5,7$ and 8 repeats) of intron 36 were found in humans (113) but they have no transactivating effect on $M U C 5 B$ promoter activity (Van Seuningen I., unpublished results). They could be involved in MUC5B mRNA stabilization as it was shown for other genes containing such repeats in their 3'end (114).

\subsection{1 p15 mucin gene regulation during mucous cell differentiation}

Another class of molecules has drawn attention in regard with mucin gene regulation as they are involved in cell differentiation and cell growth (115). Retinoids (analogs of vitamin A), as it is, are indeed essential for normal development and in the lung they control the development and maintenance of mucociliary differentiation of the airway epithelium which lines the conducting airways. The effects of all-trans-retinoic acid on mucin gene expression was studied in NHTBE cells, before and after differentiation of the stratified epithelium into a mucous-secreting epithelium. Those studies conducted by the group of Nettesheim led to the demonstration that $11 \mathrm{p} 15$ mucin genes are sequentially activated (MUC2, MUC5AC then MUC5B) during restoration of the mucous-secreting phenotype (116). MUC2 activation at $24 \mathrm{~h}$ was correlated with the appearance of mucous cells. Then, MUC5AC was activated at $48 \mathrm{~h}$ and finally $M U C 5 B$ up-regulation at $72 \mathrm{~h}$ coincided with mucin secretion (Figure 9). Among the large family of retinoid receptors (retinoic acid receptors, RARs, and retinoid X receptors, RXRs), RAR-alpha was the major retinoid receptor to both induce mucin gene expression and mucous cell differentiation. RAR-gamma also, but not as efficiently, induced mucin gene expression (117). RARs and RXRs interact with RARE elements in the promoters of target genes (118). These elements have not been identified in $M U C$ gene promoters yet. Another study in NHTBE cells confirmed the up-regulation of $M U C 5 B$ by retinoic acid (119). Thyroid hormone $\mathrm{T}_{3}$ also regulates the transcriptional activity of multitude of genes through nuclear receptors (118). Very recently, retinoid-dependent expression and transcription of MUC5AC was shown to be inhibited by $\mathrm{T}_{3}$ whereas $M U C 5 B$ was much less affected (120). This mechanism of down-regulation is thought to occur through $\mathrm{T}_{3}$-mediated repression of retinoid receptor levels and RXR-RAR/RARE complex formation.

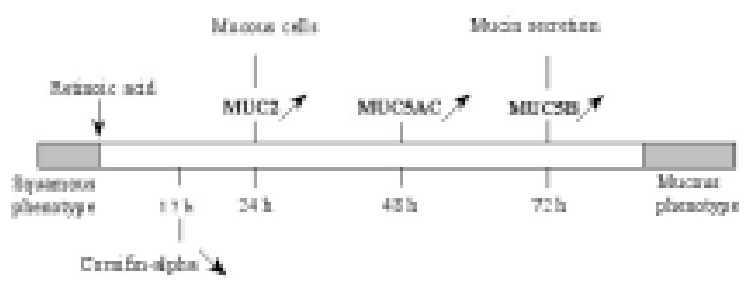

Figure 9. Restoration of mucous phenotype by retinoic acid induces sequential activation of $M U C 2, M U C 5 A C$ and $M U C 5 B$ expression (from ref. 116).

\subsection{1p15 mucin gene regulation by glucocorticoids and hormones}

Only a few studies have looked at the effects of glucocorticoids on mucin gene expression even though they are extensively used to treat inflammatory and fibrotic pulmonary and non-pulmonary disorders. Surprisingly, dexamethasone moderatly increased steady-state level of 
MUC5AC in endometrial cells (121), whereas in NCI-H292 lung cells, MUC2 and MUC5AC expression was downregulated as expected (122). Budenoside, another glucocorticoid, also inhibits IL-1-mediated-MUC2 upregulation in NCI-H292 lung cells (76). Numerous putative binding sites for glucocorticoid receptor were found within the promoters of MUC2, MUC5AC and MUC5B, which is in favor of a regulatory role for glucocorticoids in $11 \mathrm{p} 15$ mucin expression at the transcriptional level (Van Seuningen I., unpublished results).

Mucin gene expression is also altered in pathologies of the endocervical epithelium. MUC5AC, $M U C 5 B$ and MUC6 are expressed in the normal endocervical epithelium (11, 123). MUC5B and MUC4, a transmembrane mucin (9), are the major mucins and their levels are inversely related to progesterone levels. MUC5B is up-regulated at midcycle which suggests a potential role in sperm transit to uterus (124). MUC5AC mRNA is upregulated by estrogen but not by progesterone (121). Progesterone on the other hand inhibits MUC5AC upregulation by estrogen. The mechanisms that govern this anti-estrogen effect are unknown. Growth factors and cytokines are thought to play a central role in differentiation and regeneration of human uterine endometrium (125). Relationships between hormonal regulation, nuclear hormone receptors (126) and mucin gene regulation have yet to be studied and will be of great interest in pathologies related to sperm migration and reproductive processes.

\section{TRANSCRIPTIONAL REGULATION OF $11 \mathrm{P} 15$ MUCIN GENES BY THE SP-FAMILY OF TRANSCRIPTION FACTORS}

The ubiquitous transcription factor Sp1 appears to be essential in the regulation of $11 \mathrm{p} 15$ mucin genes. It has indeed been shown to bind and transactivates MUC2 (43, 127), MUC5AC and MUC5B (46). These results are however not very surprising since $11 \mathrm{p} 15$ mucin gene promoters present a high content in GC, GT and CACCC boxes, all known to bind $\mathrm{Sp1}$. It also confirms the fact that the presence of a high content of $\mathrm{CpG}$ islands in the $11 \mathrm{p} 15$ where the $M U C$ cluster is located, may also be under the control of $\mathrm{Sp} 1$ as it is known that $\mathrm{Sp} 1$ interferes with $\mathrm{CpG}$ island methylation by regulating the methyl-CpG-binding protein 2 (MeCP2) gene (128). Sp1, initially thought as a regulator of housekeeping genes, is in fact involved in the activation of many genes that are tissue-specific, cell-cycle regulated, under hormonal control and development patterning. This is explained by the fact that all these genes contain in their promoters GC boxes (GGGGCGGGG) and the related GT/CACCC box (GGTGTGGGG) that are elements required for their appropriate expression (129). GC-rich repeats have been found in $M U C 2$ promoter (43), in $M U C 5 B$ promoter and first intron (46). This kind of organization in promoters allows $\mathrm{Sp} 1$ to act synergistically by binding to multiple GC boxes to activate transcription. It is however still unknown whether $\mathrm{Sp} 1$ activates mucin gene promoters by forming homotypic interactions leading to multimeric complexes or by heterotypic interactions with different classes of nuclear proteins such as TATA-binding protein (TBP), or TBP-associated factors (dTAFII110/hTAFII130 or hTAFII55).

Sp3, another member of the Sp-family of transcription factors that is also ubiquitously expressed, may interfere with $11 \mathrm{p} 15$ mucin gene regulation as it is coexpressed with Sp1. It is known to recognize and bind to the same binding sites as Sp1. More likely, its role in activating or inhibiting Sp1-mediated target gene regulation depends on the $\mathrm{Sp} 1 / \mathrm{Sp} 3$ ratio within the cell (129). Another class of transcription factors of the zinc-finger family is to be closely regarded as important regulators of mucin gene expression as well, as they preferentially bind the GT/CACCC box. It is the Krüppel-like family of transcription factors (XKLFs) (130). In that regard, we have found a few putative binding sites for GKLF (gut-enriched Krüppel-like factor) in the promoter of $M U C 5 B$ (46).

\section{REPRESSION OF $11 P 15$ MUCIN GENES BY METHYLATION. CONSEQUENCES DURING EARLY DEVELOPMENT AND TUMORIGENESIS}

When gathering recent data concerning $11 \mathrm{p} 15$ mucin gene chromosomal localization, regulation and promoter structures, it appears that strong evidence is in favor of the involvement of methylation in the regulation of $11 \mathrm{p} 15$ mucin gene expression during early mammalian development and carcinogenesis as (i) they contain a high amount of GC-rich motifs in their promoters, (ii) Sp1 and Sp3 bind and transactivate MUC2, MUC5AC and MUC5B, (iii) the $11 \mathrm{p} 15$ region contains a high density of $\mathrm{CpG}$ islands, (iv) they display an altered expression pattern in cancers, during neoplastic transformation and progression, (v) they are expressed early during mammalian development, and finally (vi) they are repressed by methylation in cancer cell lines and tissues. This area of research is very exciting and opens new avenues into the biological roles of mucin genes during these essential biological processes of the cell. GC and GT boxes involved in the regulation of $11 \mathrm{p} 15$ mucin genes have already been identified, yet an extensive amount of work need to be performed in order to better correlate $11 \mathrm{p} 15$ mucin gene repression by methylation with (i) cell development and differentiation, (ii) imprinting and loss of heterozygoty of other genes located in the $11 \mathrm{p} 15$ region and (iii) correlate these results with epithelial cell dysfunctionment during carcinogenesis (57-59).

Our results in AGS and KATO-III gastric cancer cells demonstrate that the four $11 \mathrm{p} 15$ mucin genes are specifically repressed by methylation (Figure 10). MUC6 and $M U C 2$ and to a lower extent MUC5AC are repressed by methylation in KATO-III cells whereas $M U C 5 B$ is not. In AGS cells, only MUC2 and $M U C 5 B$ are repressed by methylation (52). The profile of $11 \mathrm{p} 15$ mucin gene repression by methylation was shown to be different in other cell lines that we have tested. Further studies are now needed to explain what is going on at the molecular level within the cluster. 


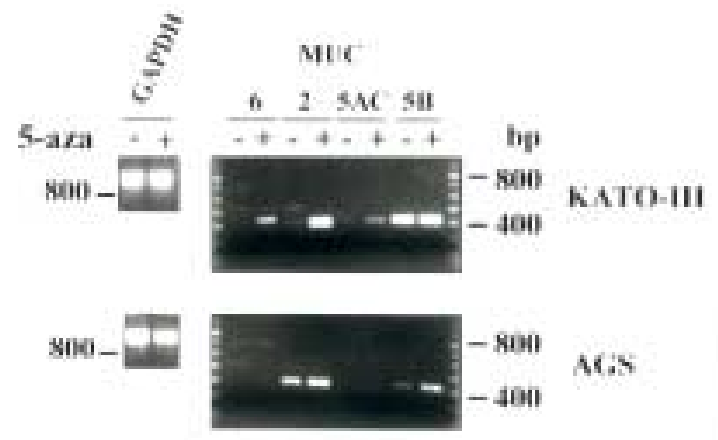

Figure 10. $11 \mathrm{p} 15$ mucin genes are regulated by methylation in KATO-III and AGS gastric cancer cells. $M U C 6, M U C 2, M U C 5 A C$ and MUC5B RT-PCR on cDNAs prepared from total RNAs extracted from untreated- and 5aza-2'-deoxycytidine-treated cells.

Sp1 binding is not affected by methylation of the cytosine in the $\mathrm{CpG}$ sequence but on the contrary seems to be essential for inhibiting methylation to occur (131). On the other hand, methylation of the outer $\mathrm{C}\left({ }^{\mathrm{m}} \mathrm{Cp}{ }^{\mathrm{m}} \mathrm{CpG}\right)$ in the $\mathrm{CpCpG}$ sequence prevents Sp1 binding (132). This mechanism could thus contribute to the high level of methylation of CG-rich domains in MUC promoters and $\mathrm{CpG}$ islands of the $11 \mathrm{p} 15$ region often observed in tumor cells. Unlike Sp1, CREB (133) and AP-2 transcription factors binding to $\mathrm{CpG}$ sites are affected by methylation. Since we showed that MUC2, MUC5AC and MUC5B bind and are co-transactivated by CREB/ATF transcription factors (Van Seuningen I., unpublished results), it will be of interest to demonstrate whether methylation of the cytosine in the TGA ${ }^{\mathrm{m}}$ CGTCA affects CREB activity on $11 \mathrm{p} 15$ mucin gene transcription.

\section{PERSPECTIVE}

In conclusion, studies about the regulation of $11 \mathrm{p} 15$ mucin gene expression have shown, up to now, that they are regulated at the transcriptional level by:

- Transcription factors that include:

- ubiquitous transcription factors $\mathrm{Sp} 1$ and $\mathrm{Sp} 3$,

- NF-kappaB, ATF-1, CREB, RAR-alpha, RARgamma,

- Exogenous factors that include:

- pro-inflammatory cytokines: IL-1beta, TNFalpha, IL-9,

- pleiotropic Th2-associated cytokines: IL-4, IL13, IL-6,

- growth factors: EGF, TGF-alpha,

- bacterial and lipid mediators: LPS, PAF, 15HETE, PGE 2 ,

- retinoids: all-trans retinoic acid,

- hormones: estrogen, $\mathrm{T}_{3}$,

- glucocorticoids: dexamethasone, budenoside,

- Intracellular signaling pathways that control mucin gene transcription involve activation of:

- PKA: ATF/CREB, AP-2,

- PKC: Sp1, NF-kappaB, AP-1,

- PKG,
- $\mathrm{Ca}^{2+}$-dependent kinases,

- Src/Ras/MAPK/pp90 $90^{\text {rsk}: ~ N F-k a p p a B, ~}$

- p42/44 MAPK: via binding to EGF-R.

Most likely other mediators, known to induce mucin secretion or yet to be characterized, participate in the regulation of $11 \mathrm{p} 15$ mucin genes at the transcriptional level and will have to be investigated (TGF-beta/Smads, IFNgamma/JAKs/STATs and TNF-alpha/TRAFs signaling pathways) (134-139). Finally, the biological significance of 11 p15 mucin gene repression by methylation during development and tumorigenesis $(140,141)$ will have to be addressed.

Availability of the promoters of three of the $11 \mathrm{p} 15$ mucin genes (MUC2, MUC5AC and MUC5B) will help in defining which regions of the promoters are involved in the expression of the gene as well as identify the cis-elements recognized by the transcription factors. One must not forget the role of intronic regions, especially the first introns that are rather large and present GC-rich regions $(M U C 5 B)$ in the regulation. It will be of great interest to isolate and characterize the promoter of the fourth 11 p15 mucin gene, MUC6, in order to (i) be able to demonstrate whether or not co-regulation of these genes occurs and (ii) understand the regulation of the whole cluster (presence of a locus control region?).

The deciphering of the regulation of mucin gene expression during cell differentiation and proliferation or during the development is mandatory in order to (i) move on to new therapeutic approaches in which mucin gene promoters could be used to direct drugs to target cells (142), (ii) use mucin genes in DNA microarray studies as potential tumor markers and prognostic indicators or (iii) use them as new therapeutic targets in inflammatory diseases of the epithelium (anti-EGF-R, anti-TNF-alpha and anti-NF-kappaB therapies) (99, 143-146). The biological significance of mucin gene expression variations in human pathophysiology of mucosal surfaces will also help those working on establishing the biological functions of mucins. Gene disruption in mice that is a powerful tool for obtaining such information will be very helpful in that regard.

\section{ACKNOWLEDGMENTS}

We would like to particularly thank Marie-Paule Ducourouble and Marie-Jeanne Freymont for typing the manuscript. This work was supported by grants from l'Association de Recherche contre le Cancer ( $\left.\mathrm{N}^{\circ} 5785\right)$ and le Comité du Nord de la Ligue Nationale contre le Cancer. M. Perrais is a recipient of a CHRU de Lille - Région Nord-Pas de Calais Ph.D. fellowship.

\section{REFERENCES}

1. Gum J. R., J. C. Byrd, J. W. Hicks, N. W. Toribara, D. T. A. Lamport \& Y. S. Kim: Molecular cloning of human intestinal mucin cDNAS. Sequences analysis and evidence for genetic polymorphism. J Biol Chem 264, 6480-6487 (1989) 
2. Aubert J.-P., N. Porchet, M. Crépin, M. DuterqueCoquillaud, G. Vergnes, M. Mazucca, B. Debuire, D. Petitprez \& P. Degand: Evidence for different human tracheobronchial mucin peptides deduced from nucleotide cDNA sequences. Am J Respir Cell Mol Biol 5, 178-185 (1991)

3. Toribara N. W., A. M. Roberton, S. B. Ho, W. L. Kuo, E. Gum, J. W. Hicks, J. R. Gum, J. C. Byrd, B. Siddiki \& Y. S. Kim: Human gastric mucin: identification of a unique species by expression cloning. J Biol Chem 268, 5879-5885 (1993)

4. Pigny P., V. Guyonnet-Dupérat, A. S. Hill, W. S. Pratt, S. Galiègue-Zouitina, M. Collyn-d'Hooge, A. Laine, I. Van-Seuningen, P. Degand, J. R. Gum, Y. S. Kim, D. M. Swallow, J.-P. Aubert \& N. Porchet: Human mucin genes assigned to $11 \mathrm{p} 15.5$ : identification and organization of a cluster of genes. Genomics 38, 340-352 (1996)

5. Porchet N., M.-P. Buisine, J.-L. Desseyn, N. Moniaux, S. Nollet, P. Degand, P. Pigny, I. Van Seuningen, A. Laine \& J.-P. Aubert: MUC genes: a superfamily of genes? Varied structures and expression patterns predict diverse and specific functions. J Soc Biol 193, 85-99 (1999)

6. Desseyn J.-L., M.-P. Buisine, N. Porchet, J.-P. Aubert, P. Degand \& A. Laine: Evolutionary history of the 11p15 human mucin gene family. J Mol Evol 46, 102-106 (1998)

7. Gendler S. J. \& A. P. Spicer: Epithelial mucin genes. Annu Rev Physiol 57, 607-634 (1995)

8. Williams S. J., M. A. McGuckin, D. C. Gotley, H. J. Eyre, G. R. Sutherland \& T. M. Antalis: Two novel mucin genes down-regulated in colorectal cancer identified by differential display. Cancer Res 59, 4083-4089 (1999)

9. Moniaux N., S. Nollet, N. Porchet, P. Degand, A. Laine \& J.-P. Aubert: Complete sequence of the human mucin gene MUC4: a putative cell membrane-associated mucin. Biochem J 338, 325-333 (1999)

10. Audié J.-P., A. Janin, N. Porchet, M.-C. Copin, B. Gosselin \& J.-P. Aubert: Expression of human mucin genes in respiratory, digestive, and reproductive tracts ascertained by in situ hybridization. J Histochem Cytochem 41, 14791485 (1993)

11. Audié J.-P, D. Tetaert, P. Pigny, M.-P. Buisine, A. Janin, J.-P. Aubert, N. Porchet \& A. Boersma: Mucin gene expression in the human endocervix. Hum Reprod 10, 98102 (1995)

12. Buisine M.-P., A. Janin, V. Maunoury, J.-P. Audie, M.P. Delescaut, M.-C. Copin, J.-F. Colombel, P. Degand, J.-P. Aubert \& N. Porchet: Aberrant expression of a human mucin gene (MUC5AC) in rectosigmoid villous adenoma. Gastroenterol 110, 84-91 (1996)
13. Vandenhaute B., M.-P. Buisine, V. Debailleul, B. Clément, N. Moniaux, M.-C. Dieu, P. Degand, N. Porchet \& J.-P. Aubert: Mucin gene expression in biliary epithelial cells. J Hepatol 27, 1057-1066 (1997)

14. Buisine M.-P., P. Desreumaux, V. Debailleul, L. Gambiez, K. Geboes, N. Ectors, M.-P. Delescaut, P. Degand, J.-P. Aubert, J.-F. Colombel \& N. Porchet: Abnormalities in mucin gene expression in Crohn's disease. Inflamm Bowel Dis 5, 24-32 (1999)

15. Copin M.-C., L. Devisme, M.-P. Buisine, C. H. Marquette, A. Wurtz, J.-P. Aubert, B. Gosselin \& N. Porchet: From normal respiratory mucosa to epidermoid carcinoma: expression of human mucin genes. Int $J$ Cancer $86,162-168$ (2000)

16. Guillem P, V. Billeret, M.-P. Buisine, J.-F. Flejou, M. Lecomte-Houcke, P. Degand, J.-P. Aubert, J.-P. Triboulet \& N. Porchet: Mucin gene expression and cell differentiation in human normal, premalignant and malignant esophagus. Int J Cancer 88, 856-861 (2000)

17. Ho S. B., G. A. Niehans, C. Lyftogt, P. S. Yan, D. L. Cherwitz, E. T. Gum, R. Dahiya \& Y. S. Kim: Heterogeneity of mucin expression in normal and neoplastic tissues. Cancer Res 53, 641-651 (1993)

18. Lesuffleur T., A. Zweibaum \& F. X. Real: Mucins in normal and neoplastic human gastrointestinal tissues. Crit Rev Oncol Hematol 17, 153-180 (1994)

19. Ho J. J. L. \& Y. S. Kim: Do mucins promote tumor cell metastasis? Int J Oncol 7, 913-926 (1995)

20. Buisine M.-P., L. Devisme, T. C. Savidge, C. Gespach, B. Gosselin, N. Porchet \& J.-P. Aubert: Mucin gene expression in human embryonic and fetal intestine. Gut 43 , 519-524 (1998)

21. Buisine M.-P., L. Devisme, M.-C. Copin, M. DurandReville, B. Gosselin, J.-P. Aubert \& N Porchet: Developmental mucin gene expression in the human respiratory tract. Am J Respir Cell Mol Biol 20, 209-218 (1999)

22. Buisine M.-P., L. Devisme, V. Maunoury, E. Deschodt, B. Gosselin, M.-C. Copin, J.-P. Aubert \& N. Porchet: Developmental mucin gene expression in the gastroduodenal tract and accessory digestive glands. I. Stomach: A relationship to gastric carcinoma. $J$ Histochem Cytochem 48, 1657-1665 (2000)

23. Buisine M.-P., L. Devisme, P. Degand, M.-C. Dieu, B. Gosselin, M.-C. Copin, J.-P. Aubert \& N. Porchet: Developmental mucin gene expression in the gastroduodenal tract and accessory digestive glands. II. Duodenum and liver, gallbladder, and pancreas. $J$ Histochem Cytochem 48, 1667-1676 (2000)

24. Abe M. \& D. Kufe: Characterization of cis-acting elements regulating transcription of the human DF3 breast 
carcinoma-associated antigen (MUC1) gene. Proc Natl Acad Sci USA 90, 282-286 (1993)

25. Kovarik A., N. Peat, D. Wilson, S. J. Gendler \& J. Taylor-Papadimitriou: Analysis of the tissue-specific promoter of the MUC1 gene. J Biol Chem 268, 9917-9926 (1993)

26. Kovarik A., J. L. Pei, J. Morris \& J. TaylorPapadimitriou: Two GC boxes ( $\mathrm{Sp} 1$ sites) are involved in regulation of the activity of the epithelium-specific $M U C 1$ promoter. J Biol Chem 271, 18140-18147 (1996)

27. Gaemers I. C., H. L. Vos, H. H. Volders, S. W. van der Valk \& J. Hilkens: A STAT-responsive element in the promoter of the episialin/MUCl gene is involved in its overexpression in carcinoma cells. J Biol Chem 276, 6191$6199(2001)$

28. Li Y., H. Kuwahara, J. Ren, G. Wen \& D. Kufe: The cSrc tyrosine kinase regulates signaling of the human DF3/MUC1 carcinoma-associated antigen with GSK3beta and beta-catenin. J Biol Chem 276, 6061-6064 (2001)

29. Spicer A. P., G. J. Rowse, T. K. Lidner \& S. J. Gendler: Delayed mammary tumor progression in Muc-1 null mice. J Biol Chem 270, 30093-30101 (1995)

30. Hilkens J., H. L. Vos, J. Wesseling, M. Boer, J. Storm, S. van der Valk, J. Calafat \& C. Patriarca: Is episialin/MUC1 involved in breast cancer progression? Cancer Lett 90, 27-33 (1995)

31. Agrawal B., S. J. Gendler, B. M. \& Longenecker: The biological role of mucins in cellular interactions and immune regulation: prospects for cancer immunotherapy. Mol Med Today 4, 397-403 (1998)

32. Rughetti A., M. Biffoni, M. Sabbatucci, H. Rahimi, I. Pellicciotta, A. Fattorossi, L. Pierelli, G. Scambia, M. Lavitrano, L. Frati \& M. Nuti: Transfected human dendritic cells to induce antitumor immunity. Gene Ther 7, 14581466 (2000)

33. Forstner G.: Signal transduction, packaging and secretion of mucins. Annu Rev Physiol 57, 585-605 (1995)

34. Marin M. G.: Update: pharmacology of airway secretion. Pharmacol Rev 46, 35-65 (1994)

35. Bradbury N. A.: Protein kinase-A-mediated secretion of mucin from human colonic epithelial cells. J Cell Physiol $185,408-415$ (2000)

36. Fischer B. M., L. G. Rochelle, J. A. Voynow, N. J. Akley \& K. B. Adler: Tumor necrosis factor-alpha stimulates mucin secretion and cyclic GMP production by guinea pig tracheal epithelial cells in vitro. Am J Respir Cell Mol Biol 20, 413-422 (1999)
37. Cohan V. L., A. L. Scott, C. A. Dinarello \& R. A. Prendergast: Interleukin-1 is a mucus secretagogue. Cell Immunol 136, 425-434 (1991)

38. Levine S. J., P. Larivée, C. Logun, C. W. Angus \& J. H. Schelhamer: Corticosteroids differentially regulate secretion of IL-6, IL-8, and GM-CSF by a human bronchial epithelial cell line. Am J Physiol 265, L360-L368 (1993)

39. Martin L. D., L. G. Rochelle, B. M. Fischer, T. M. Krunkosky \& K. B. Adler: Airway epithelium as an effector of inflammation: molecular regulation of secondary mediators. Eur Respir J 10, 2139-2146 (1997)

40. Levine S. J., P. Larivée, C. Logun, C. W. Angus, F. P. Ognibene \& J. H. Shelhamer: Tumor necrosis factor-alpha induces mucin hypersecretion and MUC-2 gene expression by human airway epithelial cells. Am J Respir Cell Mol Biol 12, 196-204 (1995)

41. Adler K. B., B. M. Fischer, D. T. Wright, L. A. Cohn \& S. Becker: Interactions between respiratory epithelial cells and cytokines: relationships to lung inflammation. Annu NY Acad Sci 725, 128-145 (1994)

42. Papadakis K. A. \& S. R. Targan: Tumor necrosis factor: Biology and therapeutic inhibitors. Gastroenterol 119, 1148-1157 (2000)

43. Gum J. R. Jr, J. W. Hicks \& Y. S. Kim: Identification and characterization of the $M U C 2$ (human intestinal mucin) gene 5'-flanking region: promoter activity in cultured cells Biochem J 325, 259-267 (1997)

44. Velcich A., L. Palumbo, L. Selleri, G. Evans \& L. Augenlicht: Organization and regulatory aspects of the human intestinal mucin gene (MUC2) locus. J Biol Chem 272, 7968-7976 (1997)

45. Li D., M. Gallup, N. Fan, D. E. Szymkowski \& C. B. Basbaum: Cloning of the amino-terminal and 5'-flanking region of the human MUC5AC mucin gene and transcriptional up-regulation by bacterial exoproducts. $J$ Biol Chem 273, 6812-6820 (1998)

46. Van Seuningen I., M. Perrais, P. Pigny, N. Porchet \& J.-P. Aubert: Sequence of the 5'-flanking region and promoter activity of the human mucin gene $M U C 5 B$ in different phenotypes of colon cancer cells. Biochem $J 348$, 675-686 (2000)

47. Ho S. B., A. M. Roberton, L. L. Shekels, C. T. Lyftogt, G. A. Niehans \& N. W. Toribara: Expression cloning of gastric mucin complementary DNA and localization of mucin gene expression. Gastroenterol 109, 735-747 (1995)

48. Bartman A. E., M.-P. Buisine, J.-P. Aubert, G. A. Niehans, N. W. Toribara, Y. S. Kim, E. J. Kelly, J. E. Crabtree \& S. B. Ho: The MUC6 secretory mucin gene is expressed in a wide variety of epithelial tissues. $J$ Pathol 186, 398-405 (1998) 
49. Reis C. A., L. David, P. Correa, F. Carneiro, C. de Bolos, E. Garcia, U. Mandel, H. Clausen \& M. SobrinhoSimoes: Intestinal metaplasia of human stomach displays distinct patterns of mucin (MUC1, MUC2, MUC5AC, MUC6) expression. Cancer Res 59, 1003-1007 (1999)

50. Balagué C., J.-P. Audié, N. Porchet, F. X. Real: In situ hybridization shows distinct patterns of mucin gene expression in normal, benign, and malignant pancreas tissues. Gastroenterol 109, 953-964 (1995)

51. Hanski C., E. Riede, A. Gratchev, H. D. Foss, C. Böhm, E. Klussmann, M. Hummel, B. Mann, H. J. Buhr, H. Stein, Y. S. Kim, J. Gum \& E. O. Riecken: MUC2 gene suppression in human colorectal carcinomas and their metastases: in vitro evidence of the modulatory role of DNA methylation. Lab Invest 77, 685-695 (1997)

52. Perrais M., P. Pigny, M.-P. Buisine, N. Porchet, J.-P. Aubert \& I. Van Seuningen-Lempire: Aberrant expression of human mucin gene $M U C 5 B$ in gastric carcinoma and cancer cells. Identification and regulation of a distal promoter. J Biol Chem 276, 15386-15396 (2001)

53. Buisine M.-P., J.-L. Desseyn, N. Porchet, P. Degand, A. Laine \& J.-P. Aubert: Genomic organization of the 3'region of the human MUC5AC mucin gene: additional evidence for a common ancestral gene for the $11 \mathrm{p} 15.5$ mucin gene family. Biochem J 332, 729-738 (1998)

54. Redeker E., J. M. N. Hoovers, M. Alders, C. J. A. van Moorsel, A. C. Ivens, S. Gregory, L. Kalikin, J. Bliek, L. de Galan, R. van den Bogaard, J. Visser, R. van der Voort, A. P. Feinberg, P. F. R. Little, A. Westerveld \& M. Mannens: An integrated physical map of 210 markers assigned to the short arm of human chromosome 11. Genomics 21, 538550 (1994)

55. Paris M. J. \& B. R. G. Williams: Characterization of a $500-\mathrm{kb}$ contig spanning the region between c-Ha-Ras and MUC2 on chromosome 11p15.5. Genomics 69, 196-202 (2000)

56. Schwienbacher C., L. Gramantier, R. Scelfo, A. Veronese, G. A. Calin, L. Bolondi, C. M. Croce, G. Barbanti-Brodano \& M. Negrini: Gain of imprinting at chromosome 11p15: A pathogenetic mechanism identified in human hepatocarcinomas. Proc Natl Acad Sci USA 97, 5445-5449 (2000)

57. Tycko B.: Epigenetic gene silencing in cancer. $J$ Clin Invest 105, 401-407 (2000)

58. Jirtle R. L., M. Sander \& J. C. Barrett: Genomic imprinting and environmental disease susceptibility. Environ Health Perspect 108, 271-278 (2000)

59. Baylin S. B. \& J. G. Herman: DNA hypermethylation in tumorigenesis. Epigenetics joins genetics. Trends Genet $16,168-174(2000)$
60. Tytgat K. M., H. A. Buller, F. J. Opdam, Y.-S. Kim, A. W. Einerhand \& J. Dekker: Biosynthesis of human colonic mucin: Muc2 is the prominent secretory mucin. Gastroenterol 107, 1352-1363 (1994)

61. Gum J. R. Jr., J. W. Hicks, A.-M. Gillespie, E. J. Carlson, L. Kömüves, S. Karnik, J. C. Hong, C. J. Epstein \& Y. S. Kim: Goblet cell-specific expression mediated by the $M U C 2$ mucin gene promoter in the intestine of transgenic mice. Am J Physiol 276, G666-G676 (1999)

62. Offner G. D., D. P. Nunes, A. C. Keates, N. H. Afdhal $\&$ R. F. Troxler: The amino-terminal sequence of MUC5B contains conserved multifunctional D domains: implications for tissue-specific mucin functions. Biochem Biophys Res Commun 251, 350-355 (1998)

63. Cardoso W. V.: Transcription factors and pattern formation in the developing lung. Am J Physiol 269, L429L442 (1995)

64. Traber $\mathrm{R} \& \mathrm{G} \mathrm{D}$ Wu: Intestinal development and differentiation. In: Gastrointestinal Cancers: biology, diagnostics, and therapy. Ed: Rustgi A K, LippincottRaven, Philadelphia 21-43 (1995)

65. Zaret K.: Developmental competence of the gut endoderm: genetic potentiation by GATA and HNF3/fork head proteins. Dev Biol 209, 1-10 (1999)

66. Corfield A. P., N. Myerscough, R. Longman, P. Sylvester, S. Arul \& M. Pignatelli: Mucins and mucosal protection in the gastrointestinal tract: new prospects for mucins in the pathology of gastrointestinal disease. Gut 47, 589-594 (2000)

67. Velcich A. \& L. H. Augenlicht: Regulated expression of an intestinal mucin gene in HT29 colonic carcinoma cells. J Biol Chem 268, 13956-13961 (1993)

68. Han S. Y., M.-S. Lee, H. R. Kim, S. H. Baek, D. H. Ahn, H. S. Chae, R. H. Erickson, M. H. Sleisenger \& Y.S. Kim: Phorbol 12-myristate 13-acetate induces alteration in mucin gene expression and biological properties of colon cancer cells. Int J Oncol 17, 487-494 (2000)

69. Hong D.-H., Petrovics G., Anderson W. B., Forstner J. \& G. Forstner: Induction of mucin gene expression in human colonic cell lines by PMA is dependent on PKCepsilon. Am J Physiol 277, G1041-G1047 (1999)

70. Enss M.-L., M. Cornberg, S. Wagner, A. Gebert, M. Henrichs, R. Eisenblätter, W. Beil, R. Kownatzki \& H. J. Hedrich: Proinflammatory cytokines trigger $M U C$ gene expression and mucin release in the intestinal cancer cell line LS180. Inflamm Res 49, 162-169 (2000)

71. Hanski C., M. Born, H. D. Foss, B. Marowski, U. Mansmann, K. Arastéh, B. Bachler, M. Papenfuss \& F. Niedobitek: Defective post-transcriptional processing of MUC2 mucin in ulcerative colitis and in Crohn's disease 
increases detectability of the MUC2 protein core. $J$ Pathol 188, 304-311 (1999)

72. Louvet B., M.-P. Buisine, P. Desreumaux, W. J. Tremaine, J.-P. Aubert, N. Porchet, M. Capron, A. Cortot, J.-F. Colombel \& W. J. Sandborn: Transdermal nicotine decreases mucosal IL- 8 expression but has no effect on mucin gene expression in ulcerative colitis. Inflamm Bowel Dis 5, 174-181 (1999)

73. Shaoul R., P. Marcon, Y. Okada, E. Cutz \& G. Forstner: The pathogenesis of duodenal gastric metaplasia: the role of local goblet cell transformation. Gut 46, 632-638 (2000)

74. Li J.-D., A. F. Dohrman, M. Gallup, S. Miyata, J. R. Gum, Y. S. Kim, J. A. Nadel, A. Prince \& C. B. Basbaum: Transcriptional activation of mucin by Pseudomonas aeruginosa lipopolysaccharide in the pathogenesis of cystic fibrosis lung disease. Proc Natl Acad Sci USA 94, 967-972 (1997)

75. Li J.-D., W. Feng, M. Gallup, J.-H. Kim, J. Gum, Y. Kim \& C. Basbaum: Activation of NF-kappaB via a Srcdependent Ras-MAPK-pp90rsk pathway is required for Pseudomonas aeruginosa-induced mucin overproduction in epithelial cells. Proc Natl Acad Sci USA 95, 5718-5723 (1998)

76. Basbaum C., H. Lemjabbar, M. Longphre, D. Li, E. Gensch \& N. McNamara: Control of mucin transcription by diverse injury-induced signaling pathways. Am J Respir Crit Care Med 160, S44-S48 (1999)

77. Dohrman A., S. Miyata, M. Gallup, J.-D. Li, C. Chapelin, A. Coste, E. Escudier, J. Nadel \& C. Basbaum: Mucin gene (MUC 2 and $M U C 5 A C$ ) upregulation by Gram-positive and Gram-negative bacteria. Biochim Biophys Acta 1406, 251-259 (1998)

78. Kim Y. D., E. J. Kwon, T. K. Kwon, S.-H. Baek, S. Y. Song \& J. S. Suh: Regulation of IL-1beta-mediated MUC2 gene in NCI-H292 human airway epithelial cells. Biochem Biophys Res Commun 274, 112-116 (2000)

79. Cornberg M., M.-L. Enss, M. K. Makkink, W. Beil, C. T. Bock, I. Sobek-Klocke, H. Mix, W. Hiller, M. P. Manns \& S. Wagner: Variation of human mucin gene expression in gastric cancer cell lines and gastric mucous cell primary cultures. Eur J Cell Biol 78, 832-841 (1999)

80. Rahman I. \& W. MacNee: Role of transcription factors in inflammatory lung diseases. Thorax 53, 601-612 (1998)

81. Temann U.-A., B. Prasad, M. W. Gallup, C. Basbaum, S. B. Ho, R. A. Flavell \& J. A. Rankin: A novel role for murine IL-4 in vivo: Induction of MUC5AC gene expression and mucin hypersecretion. Am J Respir Cell Mol Biol 16, 471-478 (1997)

82. Dabbagh K., K. Takeyama, H.-M. Lee, I. F. Ueki, J. A. Lausier \& J. A. Nadel: IL-4 induces mucin gene expression and goblet cell metaplasia in vitro and in vitro. J Immunol 162, 6233-6237 (1999)

83. Marom Z., J. H. Shelhamer, F. Sun \& M. Kaliner: Human airway monohydroxyeicosatetranoic acid generation and mucus release. J Clin Invest 72, 122-127 (1983)

84. Adler K. B., N. J. Akley \& W. C. Glasgow: Plateletactivating factor provokes release of mucin-like glycoproteins from guinea pig respiratory epithelial cells via a lipoxygenase-dependent mechanism. Am J Respir Cell Mol Biol 6, 550-556 (1992)

85. Brinkmann R. \& H. Kuhn : Regulation of 15lypoxygenase expression by cytokines. In: Eicosanoids and other bioactive lipids in cancer, inflammation and radiation injury II, ed. by K.V. Honn, New York: Plenum, p599-604 (1997)

86. Jayawickreme S. P., T. Gray, P. Nettesheim \& T. Eling: Regulation of 15-lipoxygenase expression and mucus secretion by IL-4 in human bronchial epithelial cells. Am J Physiol 276, L596-L603 (1999)

87. Gray T. E., K. Guzman, C. W. Davis, L. H. Abdullah \& P. Nettesheim: Mucociliary differentiation of serially passaged normal human tracheobronchial epithelial cells. Am J Respir Cell Mol Biol 14, 104-112 (1996)

88. Schnyder B., S. Lugli, N. Feng, H. Etter, R. A. Lutz, B. Ryffel, K. Sugamura, H. Wunderli-Allenspach \& R. Moser: Interleukin-4 (IL-4) and IL-13 bind to a shared heterodimeric complex on endothelial cells mediating vascular cell adhesion molecular-1 induction in the absence of the common gamma chain. Blood 87, 4286-4295 (1996)

89. Zuhdi Alimam M., F. M. Piazza, D. M. Selby, N. Letwin, L. Huang \& M. C. Rose: Muc-5/5ac mucin messenger RNA and protein expression is a marker of goblet cell metaplasia in murine airways. Am J Respir Cell Mol Biol 22, 253-260 (2000)

90. Lou Y.-P., K. Takeyama, K. M. Grattan, J. A. Lausier, I. F. Ueki, C. Agusti \& J. A. Nadel: Platelet-activating factor induces goblet cell hyperplasia and mucin gene expression in airways. Am J Respir Crit Care Med 157, 1927-1934 (1998)

91. Larivée P., S. J. Levine, A. Martinez, T. Wu, C. Logun \& J. H. Shelhamer: Platelet-activating factor induces airway mucin release via activation of protein kinase $\mathrm{C}$ : Evidence for translocation of protein kinase $\mathrm{C}$ to membranes. Am J Respir Cell Mol Biol 11, 199-205 (1994)

92. Narahara H. \& J. M. Johnson: Effects of endotoxins and cytokines on the secretion of platelet-activating factoracetylhydrolase by human decidual macrophages. Am J Obstet Gynecol 169, 531-537 (1993)

93. Longphre M., D. Li, M. Gallup, E. Drori, C. L. Ordornez, T. Redman, S. Wenzel, D. E. Bice, J. V. Fahy \& 
C. Basbaum: Allergen-induced IL-9 directly stimulates mucin transcription in respiratory epithelial cells. J Clin Invest 104, 1375-1382 (1999)

94. Louahed J., M. Toda, J. Jen, Q. Hamid, J.-C. Renauld, R. C. Levitt \& N. C. Nicolaides: Interleukin-9 upregulates mucus expression in the airways. Am J Respir Cell Mol Biol 22, 649-656 (2000)

95. Voynow J. A., L. Rosenthal Young, Y. Wang, T. Horger, M. C. Rose \& B. M. Fischer: Neutrophil elastase increases MUC5AC mRNA and protein expression in respiratory epithelial cells. Am J Physiol 276, L835-L843 (1999)

96. Fischer B. \& J. Voynow: Neutrophil elastase induces MUC5AC messenger RNA expression by an oxidantdependent mechanism. Chest 117, 317S-320S (2000)

97. Li-Yun Chang T., X. Peng \& X.-Y. Fu: Interleukin-4 mediates cell growth inhibition through activation of Stat1. J Biol Chem 275, 10212-10217 (2000)

98. Bauer J. H., K. D. Liu, Y. You, S. Y. Lai \& M. A. Goldsmith: Heterodimerization of the gamma chain with interleukin-9 receptor alpha subunit leads to STAT activation and prevention of apoptosis. J Biol Chem 273, 9255-9260 (1998)

99. Davies D. E., R. Polosa, S. M. Puddicombe, A. Richter \& S. T. Holgate: The epidermal growth factor receptor and its ligand family: their potential role in repair and remodelling in asthma. Allergy 54, 771-783 (1999)

100. Ruocco S., A. Lallemand, J. M. Tournier \& D. Gaillard: Expression and localization of epidermal growth factor, transforming growth factor-alpha, and localization of their common receptor in fetal human lung development. Pediatr Res 39, 448-455 (1996)

101. Takeyama K., K. Dabbagh, H.-M. Lee, C. Agusti, J. A. Lausier, I. F. Ueki, K. M. Grattan \& J. A. Nadel: Epidermal growth factor system regulates mucin production in airways. Proc Natl Acad Sci USA 96, 30813086 (1999)

102. Takeyama K., K. Dabbagh, J. J. Shim, T. Dao-Pick, I. F. Ueki \& J. A. Nadel: Oxidative stress causes mucin synthesis via transactivation of epidermal growth factor receptor: role of neutrophils. J Immunol 164, 1546-1552 (2000)

103. Lee H.-M., K. Takeyama, K. Dabbagh, J. A. Lausier, I. F. Ueki \& J. A. Nadel: Agarose plug instillation causes goblet cell metaplasia by activating EGF receptors in rat airways. Am J Physiol 278, L185-L192 (2000)

104. Takeyama K., B. Jung, J. J. Shim, P.-R. Burgel, T. Dao-Pick, I. F. Ueki, U. Protin, P. Kroschel \& J. A. Nadel: Activation of epidermal growth factor receptors is responsible for mucin synthesis induced by cigarette smoke. Am J Physiol 280, L165-L172 (2001)
105. Burgel P.-R., E. Escudier, A. Coste, T. Dao-Pick, I. F. Ueki, K. Takeyama, J. J. Shim, A. H.Murr \& J. A. Nadel: Relation of epidermal growth factor receptor expression to goblet cell hyperplasia in nasal polyps. J Allergy Clin Immunol 106, 705-712 (2000)

106. Borchers M. T., S. Wesselkamper, S. E. Wert, S. D. Shapiro \& G. D. Leikauf: Monocyte inflammation augments acrolein-induced Muc5ac expression in mouse lung. Am J Physiol 277, L489-L497 (1999)

107. Borchers M. T., M. P. Carty \& G. D. Leikauf: Regulation of human airway mucins by acrolein and inflammatory mediators. Am J Physiol 276, L549-L555 (1999)

108. Longphre M., D. Li, J. Li, E. Matovinovic, M. Gallup, J. M. Samet \& C. B. Basbaum: Lung mucin production is stimulated by the air pollutant residual oil fly ash. Toxicol Appl Pharmacol 162, 86-92 (2000)

109. Shim J. J., K. Dabbagh, I. F. Ueki, T. Dao-Pick, P.-R. Burgel, K. Takeyama, D. C.-W. Tam \& J. A. Nadel: IL-13 induces mucin production by stimulating epidermal growth factor receptors and by activating neutrophils. Am J Physiol 280, L134-L140 (2001)

110. Sassone-Corsi P.: Transcription factors responsive to cAMP. Annu Rev Cell Dev Biol 11, 355-377 (1995)

111. Desseyn J.-L., J.-P. Aubert, I. Van Seuningen, N. Porchet \& A. Laine: Genomic organization of the 3 ' region of the human mucin gene MUC5B. J Biol Chem 272, 16873-16883 (1997)

112. Pigny P., I. Van Seuningen, J.-L. Desseyn, S. Nollet, N. Porchet, A. Laine \& J.-P Aubert: Identification of a 42kDa nuclear factor (NF1-MUC5B) from HT-29 MTX cells that binds to the 3 ' region of human mucin gene MUC5B. Biochem Biophys Res Commun 220, 186-191 (1996)

113. Desseyn J.-L., K. Rousseau \& A. Laine: Fifty-nine bp repeat polymorphism in the uncommon intron 36 of the human mucin gene MUC5B. Electrophoresis 20, 10571066 (1999)

114. Nakamura Y., K. Koyama \& M. Matsushima: VNTR (variable number of tandem repeat) sequences as transcriptional, translational, or functional regulators. $J$ Hum Genet 43, 149-152 (1998)

115. Gudas, L J, M B Sporn \& A B Roberts: Biological activities of the retinoids. In: The retinoids: Biology, Chemistry and Medicine. Eds: Sporn M B, Roberts A B, Goodman D S, Raven Press, NY 443-520 (1994)

116. Koo J. S., J.-H. Yoon, T. Gray, D. Norford, A. M. Jetten \& P. Nettesheim: Restoration of the mucous phenotype by retinoic acid in retinoid-deficient human bronchial cell cultures: changes in mucin gene expression. Am J Respir Cell Mol Biol 20, 43-52 (1999) 
117. Koo J. S., A. M. Jetten, P. Belloni, J.-H. Yoon, Y.-D. Kim \& P. Nettesheim: Role of retinoid receptors in the regulation of mucin gene expression by retinoic acid in human tracheobronchial epithelial cells. Biochem $J$ 338, 351-357 (1999)

118. Mangelsdorf D. J., C. Thummel, M. Beato, P. Herrlich, G. Schutz, K. Umesono, B. Blumberg, P. Kastner, M. Mark, P. Chambon \& R. M. Evans: The nuclear receptor superfamily: the second decade. Cell 83, 835-839 (1995)

119. Bernacki S. H., A. L. Nelson, L. Abdullah, J. K. Sheehan, A. Harris, C. W. Davis \& S. H. Randell: Mucin gene expression during differentiation of human airway epithelia in vitro. MUC4 and MUC5B are strongly induced. Am J Respir Cell Mol Biol 20, 595-604 (1999)

120. Gray T., P. Nettesheim, C. Basbaum \& J.-S. Koo: Regulation of mucin gene expression in human tracheobronchial epithelial cells by thyroid hormone. Biochem J 353, 727-734 (2001)

121. Gollub E. G., H. Waksman, S. Goswami \& Z. Marom: Mucin genes are regulated by estrogen and dexamethasone. Biochem Biophys Res Commun 217, 1006-1014 (1995)

122. Kai H., K. Yoshitake, A. Hisatsune, T. Kido, Y. Isohama, K. Takahama \& T. Miyata: Dexamethasone suppresses mucus production and MUC-2 and MUC-5AC gene expression by NCI-H292 cells. Am J Physiol 271, L484-L488 (1996)

123. Gipson I. K., S. Spurr-Michaud, R. Moccia, Q. Zhan, N. Toribara, S. B. Ho, A. R. Gargiulo \& J. A. Hill: MUC4 and MUC5B transcripts are the prevalent mucin messenger ribonucleic acids of the human endocervix. Biol Reprod 60, 58-64 (1999)

124. Gipson I. K., R. Moccia, S. Spurr-Michaud, P. Argüeso, A. R. Gargiulo, J. A. Hill III, G. D. Offner \& H. T. Keutmann: The amount of MUC5B mucin in cervical mucus peaks at midcycle. J Clin Endocrinol Metab 86, 594-600 (2001)

125. Giudice L. C.: Growth factors and growth modulators in human uterine endometrium: their potential relevance to reproductive medicine. Fertil Steril 61, 1-17 (1994)

126. Freedman L. P. \& B. F. Luisi: On the mechanism of DNA binding by nuclear hormone receptors: A structural and functional perspective. $J$ Cell Biochem 51, 140-150 (1993)

127. Aslam F., L. Palumbo, L. H. Augenlicht \& A. Velcich: The Sp Family of transcription factors in the regulation of the human and mouse MUC2 gene promoters. Cancer Res $61,570-576(2001)$

128. Marin M., A. Karis, P. Visser, F. Grosveld \& S. Philipsen: Transcription factor Sp1 is essential for early development but dispensable for cell growth and differentiation. Cell 89, 619-628 (1997)

129. Suske G.: The Sp-family of transcription factors. Gene 238, 291-300 (1999)

130. Philipsen S. \& G. Suske: A tale of three fingers: the family of mammalian Sp/XKLF transcription factors. $\mathrm{Nucl}$ Acids Res 27, 2991-3000 (1999)

131. Brandeis M., D. Frank, I. Keshet, Z. Siegfried, M. Mendelsohn, A. Nemes, V. Temper, A. Razin \& H. Cedar: Sp1 elements protect a $\mathrm{CpG}$ island from de novo methylation. Nature 371, 435-438 (1994)

132. Clark S. J., J. Harrison \& P. L. Molloy: Sp1 binding is inhibited by ${ }^{\mathrm{m}} \mathrm{Cp}{ }^{\mathrm{m}} \mathrm{CpG}$ methylation. Gene 195, 67-71 (1997)

133. Iguchi-Ariga S. M. M. \& W. Schaffner: CpG methylation of the cAMP-responsive enhancer/promoter sequence TGACGTCA abolishes specific factor binding as well as transcriptional activation. Genes Dev 3, 612-619 (1989)

134. Massagué J.: TGF-beta signal transduction. Annu Rev Biochem 67, 753-791 (1998)

135. Roberts A. B.: TGF-beta signaling from receptors to the nucleus. Microb Infect 1, 1265-1273 (1999)

136. Park C. \& C. Schindler: Protein-DNA interactions in interferon-gamma signaling. Meth Enzymol 15, 175-188 (1998)

137. Pellegrini S. \& I. Dusanter-Fourt: The structure, regulation and function of the janus kinases (JAKs) and the signal transducers and activators of transcription (STATs). Eur J Biochem 248, 615-633 (1997)

138. Holtzman M. J., S. L. Brody \& D. C. Look: Does gene therapy call for "STAT" immunity and inflammation at the epithelial barrier? Am J Respir Cell Mol Biol 12, 127-129 (1995)

139. Paludan S. R.: Synergistic action of pro-inflammatory agents: cellular and molecular aspects. J Leukoc Biol 67, 18-25 (2000)

140. Edwards P. A. W.: The impact of developmental biology on cancer research: an overview. Cancer \& Metast Rev 18, 175-180 (1999)

141. Heby O.: DNA methylation and polyamines in embryonic development and cancer. Int J Dev Biol 39, 737757 (1995)

142. Nettelbeck, D. M., V. Jérôme \& M. Müller: Gene therapy. Designer promoters for tumour targeting. Trends Genet 16, 174-181 (2000) 
Transcriptional Regulation of 11p15 Mucin Genes

143. Opal S. M. \& V. A. DePalo: Anti-inflammatory cytokines. Chest 117, 1162-1172 (2000)

144. Fein A. M. \& E. M. Abraham: Can we make sense out of cytokines? Chest 117, 932-934 (2000)

145. Tak P. P. \& G. S. Firestein: NF-kappaB: a key role in inflammatory diseases. J Clin Invest 107, 7-11 (2001)

146. Baldwin A. S.: Control of oncogenesis and cancer therapy resistance by the transcription factor NF-kappaB. $J$ Clin Invest 107, 241-246 (2001)

Keywords: Mucins, Regulation, Transcription, Promoter, 11p15, Cancer, Therapy, Methylation, Cytokines, Growth Factors, Inflammation, MUC2, MUC5AC, MUC5B, MUC6, Sp1, Sp3, NF-kappaB, ATF-1, CREB, AP-1, Differentiation, Development, Tumorigenesis, Lung, Colon, Gastrointestinal, Hormones, Review.

Send correspondence to: Dr Isabelle Van Seuningen, Ph.D., Unité INSERM 377, Place de Verdun, F-59045 Lille cedex, France, Tel: 33-320-29-88-65, Fax: 33-320-53-8562, E-mail: vanseuni@ 1ille.inserm.fr

\section{DEAR AUTHOR:}

The manuscript underwent formatting changes. This causes the Greek letters to be lost in some instances. Please check the manuscript thoroughly to insure that these are restored. We highly recommend that you use English equivalents. 